\title{
Artelogie
}

artelogie Recherche sur les arts, le patrimoine et la littérature de l'Amérique latine

$6 \mid 2014$

Horizons et dispositifs des arts plastiques des pays du Río de la Plata (XXe siècle)

\section{La distancia y el lugar: producciones visuales entre el Plata y el Sena durante los años sesenta}

Isabel Plante

\section{(2) OpenEdition \\ Journals}

Edición electrónica

URL: http://journals.openedition.org/artelogie/1328

DOI: $10.4000 /$ artelogie. 1328

ISSN: 2115-6395

Editor

Association ESCAL

Referencia electrónica

Isabel Plante, «La distancia y el lugar: producciones visuales entre el Plata y el Sena durante los años sesenta », Artelogie [En línea], 6 | 2014, Publicado el 24 junio 2014, consultado el 20 abril 2019. URL http://journals.openedition.org/artelogie/1328; DOI : 10.4000/artelogie.1328

Este documento fue generado automáticamente el 20 abril 2019.

Association ESCAL 


\title{
La distancia y el lugar: producciones visuales entre el Plata y el Sena durante los años sesenta
}

\author{
Isabel Plante
}

Hoy volvimos a Saint Germain, al drugstore de los posters, a terminar la baguette entre rostros del Che, Fidel con Camilo, Lumumba, el tío Ho, [...] Todo se vuelve bello en el drugstore, posible, encuadrable, continuo, digno de ser visto, el mundo reaparece colgado del techo, con rostros pegados en las paredes, desde Kim Novak en Vértigo o Ana Karina consagrada por Godard a los colores duros del napalm en los arrozales. Hasta el marmota de Onganía podría quedar suspendido en el aire sin quebrar las armonías del lugar: general

del Tercer Mundo, proimperialista, diría el catálogo del mostrador. El consumo de objetos de izquierda fue siempre novedoso, acompañante de

las teorías. Irrumpe inesperado en las nuevas decoraciones, y además mucho más barato. Mercancía de caras prohibidas allá en el sur, seres oprobiosos para los poderes. Por eso tal vez uno necesita comprarlos por pocos francos, verlos colgados de las paredes de los pies de la cama, frente al escritorio, junto al espejo del baño, al lado de las latas de duraznos en almíbar, como un pasaje gratuito y personal hacia una casa escondida, hacia un sótano repentino de uno mismo, hacia una clandestinidad sin testigos ni 
mayores argumentos.

Nicolás Casullo, notas del 12 de abril de 1968.

1: Tapa de la revista Opus International n. 3, octobre 1967

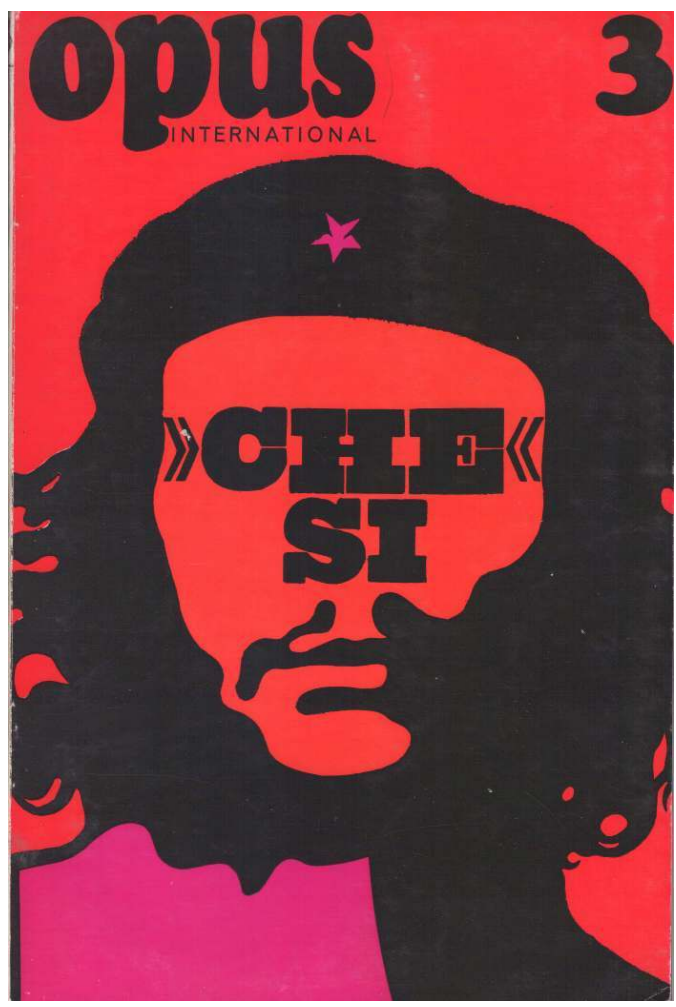

1 Hacia fines de los años sesenta, en Francia se multiplicaron las imágenes del che Guevara (el tercer número de la revista Opus International llevaba en la tapa una silueta de su rostro), se escuchó música andina o venezolana (el mismo Jesús Rafael Soto tocaba la guitarra y cantaba), y se leyó con avidez la novela Cien años de soledad de Gabriel García Márquez, que había sido traducida al francés en 1968, solo un año después de su primera publicación en castellano. El interés creciente por una "cultura latinoamericana" llevó a Damián Bayón -uno de los "argentinos de París"- a sostener en 1974 que América latina estaba de moda (BAYÓN, 1974: 9).

2 Las reflexiones de Nicolás Casullo citadas son las que escribió en su diario de viaje a Europa de 1968 y retomó mucho más tarde en el libro que publicó en ocasión de los treinta años del Mayo francés (CASULLO, 1988). Su testimonio repone la dimensión afectiva del consumo de íconos de la izquierda tercermundista, en su variedad, y liga la apropiación íntima de esas imágenes con las posibilidades efectivas de exhibirlas públicamente en París, lejos de su lugar de procedencia.

En efecto, como parte de esa proliferación de imágenes del tercermundismo, la circulación de íconos latinoamericanos llegó a tal punto que la Coopérative des Malassis ironizaba en obras como L'Appartemensonge (1971) con la moda castrista difundida entre los intelectuales franceses, a quienes tildaban de "revolucionarios de cámara". ${ }^{1}$ Uno de los paneles que conforman esta obra representaba a una pareja dentro de la cama. Por detrás, en el empapelado de la habitación se reconoce el retrato emblemático del Che Guevara en su versión 'esténcil', sin sombras ni grises, reducido a motivo decorativo. Así como la guerra de Vietnam se constituyó como un emblema del antimperialismo, y sus 
imágenes aparecieron, por ejemplo, en las pinturas de Erró (nacido en Islandia y residente en París), Latinoamérica conformó otro núcleo temático potente. Y si los encuentros de artistas latinoamericanos de La Habana y Santiago de Chile realizados en 1972 fueron una suerte de caldera donde se discutía la idea de un arte revolucionario para Latinoamérica (MARCHESI, 2012), París constituyó uno de los lugares privilegiados de visibilidad internacional para imágenes de inspiración regional.

Durante los años sesenta y hasta mediados de la década siguiente, cuando el golpe de estado de 1973 puso fin al acceso chileno al socialismo por la vía democrática, América latina ocupó un lugar privilegiado en el imaginario francés. Las rupturas y alineamientos en el proceso revolucionario cubano desde 1959, los problemas de la transposición del modelo foquista, la instauración de una dictadura en Brasil en 1964, los debates en torno de la muerte del Che Guevara en septiembre de 1967, constituyeron disparadores de un latinoamericanismo nuevo que llevó a conocer mejor la región. Así, en Francia proliferaron artículos periodísticos, números especiales de revistas y libros sobre América latina: entre 1965 y 1969, alrededor de 150 libros y 2000 artículos, sin contar diarios y semanarios (CHONCHOL y MARTINIERE, 1985). El entusiasmo fue tal que, en su crítica a la izquierda gala, el escritor y periodista Jean-François Revel se refería al "mito del Tercer Mundo revolucionario" (REVEL, 1970, 63).

5 Junto con la candente actualidad política de la región, el llamado boom de la literatura latinoamericana en Francia (AA.VV., 1984). y el reconocimiento logrado por algunos miembros de la comunidad cultural sudamericana de París, contribuyeron a dar visibilidad y prestigio al mundo intelectual del nuevo continente. Esa comunidad sudamericana tuvo una actividad más o menos conjunta desde 1962 (PLANTE, 2013) y contaba con algunos notables como Julio Cortázar o Julio Le Parc, que se comprometieron con la "causa latinoamericana".

6 James Clifford advierte que la paradoja que da fuerza a una diáspora es que "residir aquí supone solidaridad y conexión allá. Pero allá no es necesariamente un solo lugar o una nación exclusiva" (CLIFFORD, 1999: 325) Para este autor, una pregunta central respecto de la conformación de sujetos diaspóricos sería ¿cómo se recuerda y rearticula la conexión (en otra parte) que establece una diferencia (aquí)? En este sentido, presenta un par de casos de lo que denomina estructuración negativa de redes diaspóricas, esto es de identificación supranacional por contraste u oposición : una identificación magrebí une a argelinos, marroquíes y tunecinos residentes en Francia, pues una historia común colonial y neo-colonial contribuye a establecer nuevas solidaridades; de modo similar, hacia 1970 se formaron en Gran Bretaña alianzas antirracistas entre inmigrantes sudasiáticos, afro-caribeños y africanos en contra del término excluyente "negro". Resulta productivo pensar en esta clave el caso de la identificación latinoamericana de los intelectuales argentinos residentes en París, aunque no es posible afirmar que fueran víctimas de discriminaciones raciales o sociales. Por el contrario, en algunos círculos ese origen aportaba cierto capital cultural.

7 En cualquier caso, entre fines de los años sesenta y comienzos de los setenta, buena parte de los artistas argentinos radicados en París se sintieron interpelados por los discursos latinoamericanistas, y rearticularon su producción y sus actividades en relación con estas cuestiones. La imagen que se tenía en Francia de ellos como una comunidad cultural relativamente homogénea (entre pre-capitalista y revolucionaria) no era ajena a la configuración, por parte de los intelectuales del nuevo continente, de un latinoamericanismo que se insertaba en la solidaridad del Tercer Mundo y en particular 
con la experiencia revolucionaria cubana. ${ }^{2}$ De allí que estudiar la producción de los artistas argentinos en París durante este período implique utilizar con frecuencia el término 'latinoamericano'. En muchos casos, estos gentilicios resultaban intercambiables. No sólo para la crítica francesa, que podía desconocer las divisiones políticas del mapa sudamericano, sino también para los mismos artistas. A su vez, la identificación latinoamericana de los argentinos se combinó, según los casos, con la procedencia de una metrópoli sudamericana como la modernizada Buenos Aires de los años sesenta, con la propia ascendencia italiana, española, francesa o polaca, y con los vínculos establecidos con la cultura europea.

8 Para esos artistas e intelectuales extranjeros, habitar París consistió en no ser foráneos al arte -esto es, participar del juego de fuerzas del campo artístico por antonomasia- ${ }^{3} \mathrm{y}$, al mismo tiempo, ejercitar su latinoamericanidad. Si bien no se abocaron con exclusividad a recrear imágenes para la región, sí dieron visibilidad a ciertos aspectos significativos. Retomaron los tópicos del mapa y la naturaleza americana, que sumaron al imaginario de una región con vocación revolucionaria. Frente a imágenes vagas y exotizantes, o ante el uso exclusivo de íconos del tercermundismo para identificar a la región, buena parte de los artistas argentinos de París buscaron otras representaciones, que se distanciaran de los clichés asociados al continente.

9 Sin dudas, la circulación francesa de discursos e imágenes relativas al Tercer Mundo durante esos años exceden las escenas latinoamericanas. Este artículo no pretende establecer una comparación con otros focos de atención de la Nueva Izquierda francesa, como Budapest, Argelia o Praga. Sus objetivos son ya amplios : rastrear el lugar de Latinoamérica en el contexto de ese tercermundismo, y en particular examinar los modos en que los artistas argentinos residentes en París incorporaron en su trabajo la emergencia internacional de América Latina, y cómo participaron ellos mismos de ese fenómeno.

10 El conjunto de producciones visuales que nos ocupa en este artículo conforma una suerte de amalgama heterogénea que, aunque no se limita a la reproducción de íconos de la izquierda tercermundista, guarda cierto paralelo con la yuxtaposición en el drugstore que describe Casullo en la cita de inicio. Le Parc, uno de los cinetistas de perfil más alto, formó parte de la organización de Amérique Latine non-officielle, una exhibición montada de manera anónima y colectiva en la ciudad universitaria de París durante abril de 1970. En la obra de Nicolás García Uriburu, el color verde y el mapa de Sudamérica son motivos recurrentes desde mediados de los años sesenta. Hacia 1969 Antonio Seguí realizó e hizo circular por Europa una serie de pinturas que representan paisajes entre pintorescos e indefinidos de la provincia de Córdoba, pero sólo pueden identificarse a partir de su título. Entre 1965 y 1972, buena parte de los proyectos artísticos de Lea Lublin pusieron en relación la exploración del estatus de las imágenes con la crítica institucional, a la vez que articularon las escenas artística y política latinoamericanas con la ciudad de París.

11 Esta variedad de materialidades, dispositivos, estilos y estrategias resulta un desafío para quienes deseamos evitar explicaciones simplificadoras, pero enriquece el análisis a la hora de dilucidar los modos en que cada uno de estos migrantes moduló en su obra las nociones de lugar y de distancia. ¿Cuáles fueron, entonces, las alusiones metafóricas e inscripciones sitio-específicas que ensayaron? ¿Se puede pensar en algo así como interpelaciones de lo local para analizar buena parte de la producción artística de los 'argentinos de París'? 


\section{París, el lugar para una Amérique Latine non-officielle} cuya primera exhibición reunió en el Musée d'Art Moderne de la Ville de Paris (MAMVP), desde agosto hasta octubre, el trabajo de 138 artistas residentes en esa ciudad, entre quienes sobresalían las figuras consagradas de Wifredo Lam, Roberto Matta y Rufino Tamayo. El conjunto estaba signado por una mayoría de obras abstractas, tanto cinéticas como informales. Además de las reproducciones de obras, el catálogo contenía traducciones al francés de textos de Cortázar, César Vallejo, Vicente Huidobro, Gabriela Mistral, Miguel Ángel Asturias, Carlos Drummond de Andrade, Pablo Neruda, Nicolás Guillén, Vinicius de Moraes, Octavio Paz, Julio Llinás y Roberto Fernández Retamar, entre otros.

En el marco de la exposición se organizaron lecturas de poemas y conciertos de música folklórica a cargo de las agrupaciones Los Guaranies, Los Calchaquíes y Los Incas. También se incorporó al programa la escucha de tres obras compuestas por el argentino Edgardo Cantón, del Groupe de Recherches Musicales de la Radio Télévision Française. La iniciativa en su conjunto estuvo encabezada por el escritor y crítico Jean-Clarence Lambert ${ }^{4} \mathrm{y}$ un comité organizador integrado por Agustín Cárdenas, Carlos Cairoli, Perán Erminy, Rodolfo Krasno, Wifredo Lam, Silvano Lora, Roberto Matta, Alicia Penalba, Arhur Luis Piza, Oswaldo Vigas y Enrique Zañartu. Y la financiación del evento dependió del esfuerzo de los artistas, ya que las embajadas de Brasil, Cuba, México y Venezuela adhirieron en forma simbólica.

Tres años más tarde, en junio de 1965, esta asociación de intelectuales latinoamericanos organizó otra exposición con alrededor de 130 artistas en ese mismo museo, Artistes latinoaméricains de Paris. Y para 1968 planificaba una nueva exhibición con un título muy similar a los anteriores, Art Latino-américain à Paris. Según el reglamento mecanografiado que Le Parc conserva en sus archivos, iba a inaugurarse el 28 de junio en el MAMVP. Pero ante el inicio de los conflictos del Mayo francés, el comité de organización convocó a los participantes a una asamblea general el 13 de mayo. El objetivo planteado para esta asamblea era "la definición de la orientación de la exposición en el contexto del conjunto de problemas de los pueblos latinoamericanos, y el establecimiento de los programas que complementarán esta manifestación". ${ }^{5}$ El día elegido para esta reunión fue también el de la asamblea de artistas en la Sorbona que terminó con la toma del atelier de litografía de la École Nationale de Beaux Arts, donde rápidamente comenzó a funcionar el Atelier Populaire. En este contexto, es probable que la exposición quedara sin efecto. ${ }^{6}$ Pero la iniciativa se reformuló. Si los intelectuales latinoamericanos se nucleaban a partir de su procedencia, con independencia de las afinidades estéticas, hacia fines de los años sesenta esa suerte de fraternidad tomó un tono militante. 

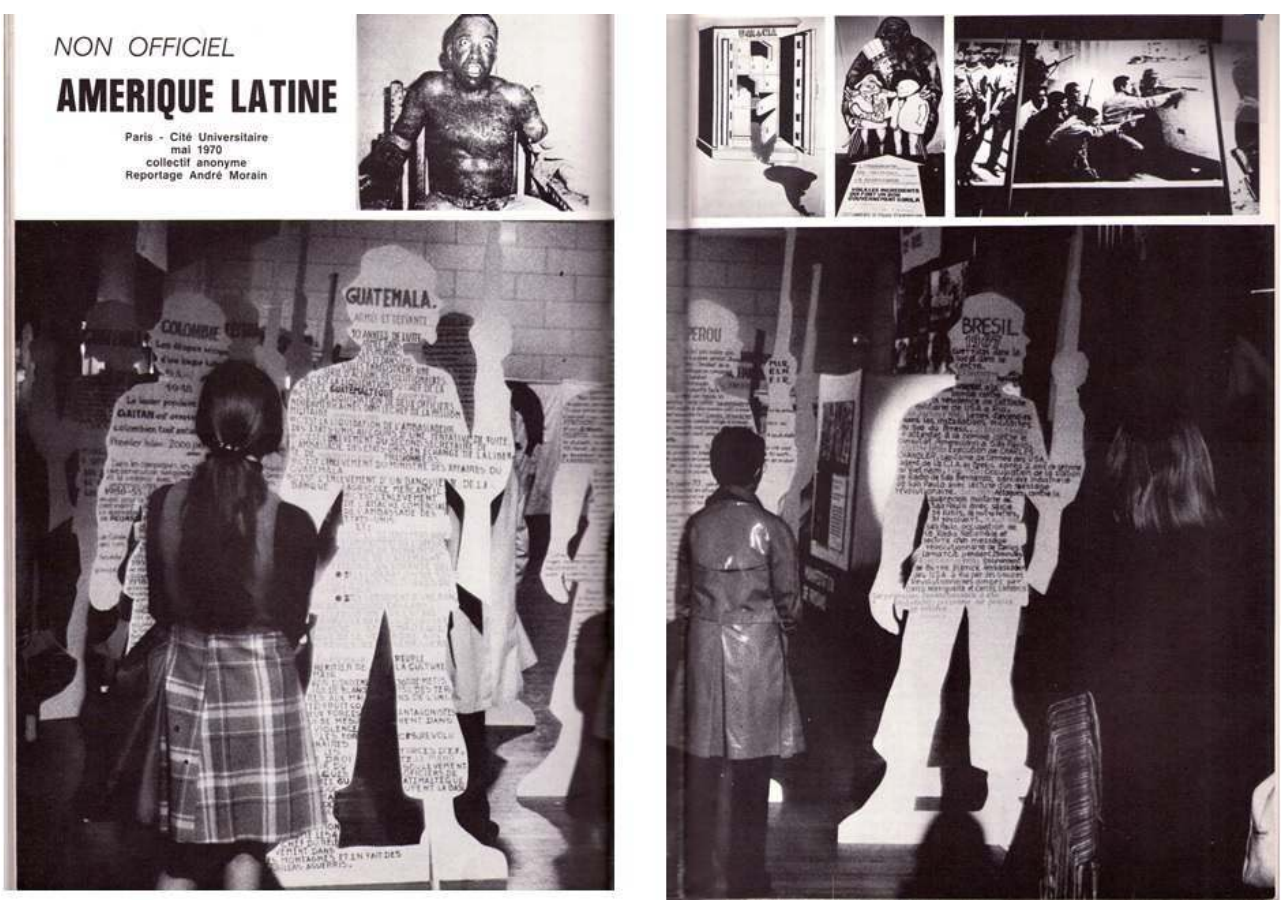

Opus International n. 18, juin 1970, pp. 54-55.

Amérique Latine non-officielle, organizada en el teatro de la Cité Universitaire del 20 al 30 de abril de 1970, fue una nueva versión de esas exposiciones latinoamericanas, una reedición anónima y engagée. El colectivo de artistas montó la exhibición fuera del circuito de las artes visuales: el predio ubicado en el extremo Sur de la capital francesa que reúne diversas residencias para estudiantes universitarios. Sobrellevando algunas "deserciones" -tal como las llamó Le Parc- el grupo mantuvo el anonimato. La firma habría desviado la atención del objetivo central: "sensibilizar sobre los problemas latinoamericanos y suscitar la colaboración activa". ${ }^{7}$ En este sentido, la apuesta a la producción sin identificación de los autores era similar a la del Atelier Populaire, donde se produjeron los afiches del mayo francés (PLANTE, 2011).

La exhibición consistió en un recorrido articulado mediante imágenes en diversos soportes (carteles, fotografías, pinturas), textos escritos y audiovisuales. Entre paneles con escenas sangrientas, caricaturas políticas y siluetas del Che Guevara recortadas en cartón, el espectador era orientado hacia la "desmitificación" de América latina. Se pretendía dejar en claro que Latinoamérica no era sólo un destino turístico o un lugar exótico, sino la tierra de el guerrillero, de la intervención militar y la tortura, y del "imperialismo yankee". En palabras de Le Parc, "una exposición para denunciar la situación social en América latina. Se mostraban las luchas que se hacían, se informaba, se despertaba entre los franceses una cierta simpatía más activa". ${ }^{8}$ Las fotografías que conserva este artista muestran que la exhibición ocupó una gran superficie en el edificio central de la ciudad universitaria y contaba con secciones organizadas alrededor de diversos temas. 
3 Vistas de la exposición Amérique Latine Non Officielle (1970)

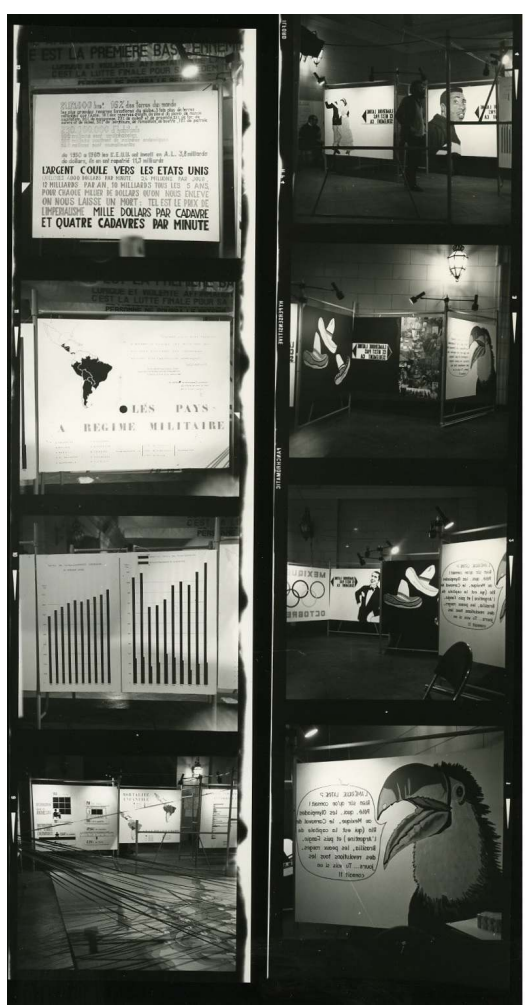

Cité Universitaire,Paris. Archivo Le Parc.

Una sección utilizaba el mapa de Latinoamérica, banderas de los diversos países y motivos "típicos" como el perico, sombreros mexicanos o la figura de Carlos Gardel, junto con abundante información sobre los movimientos emancipatorios, los focos guerrilleros y los regímenes militares de la región. Otra sección, "Las luchas populares", reunía paneles con imágenes y textos referidos a "manifestaciones en las calles", "manifestaciones campesinas", "lucha armada" y "ocupación de fábricas". En otro sector se disponían retratos de ciertos héroes de las independencias latinoamericanas: Simón Bolívar, José de San Martín, José Martí, Emiliano Zapata y el Tiradentes (Joaquín José da Silva Xavier). Estos próceres aparecían menos vinculados a las diversas historias nacionales que a un panteón común del subcontinente, que retomaba en buena medida la idea bolivariana de un "hemisferio americano", expresada en la célebre "Carta de Jamaica" (1815). Una sala alargada estaba atravesada de lado a lado por una serie de pasacalles inscriptos con consignas como "le seul dialogue avec l'impérialisme c'est s'armer" (el único diálogo posible con el imperialismo es armarse) y "torture" (tortura), todos en francés. 
4 Algunos afiches en Amérique Latine non Officielle (1970): dos provenientes de la exposición Malvenido Rockfeller (Archivo León Ferrari) y Non à la Biennale, portada del dossier que reunió en París proclamas relativas al boicot a la Bienal de San Pablo de 1969.

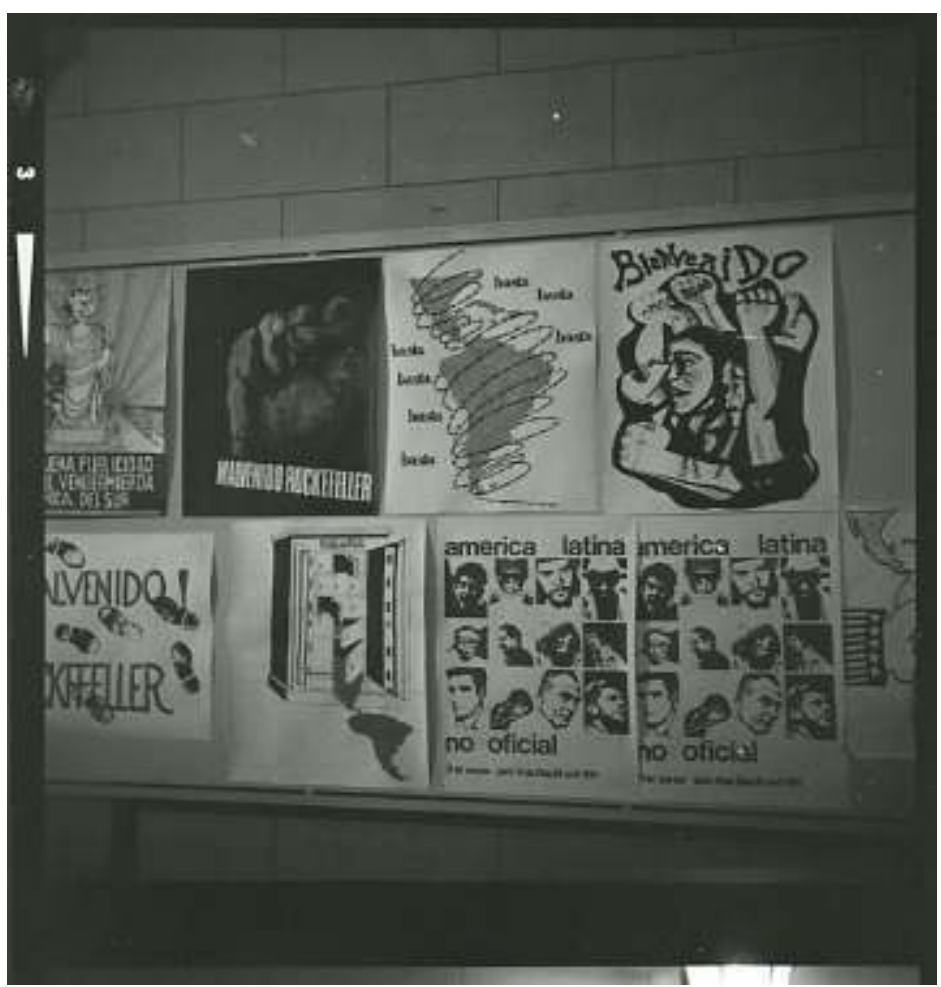

4 Algunos afiches en Amérique Latine non Officielle (1970): dos provenientes de la exposición Malvenido Rockfeller (Archivo León Ferrari) y Non à la Biennale, portada del dossier que reunió en París proclamas relativas al boicot a la Bienal de San Pablo de 1969.

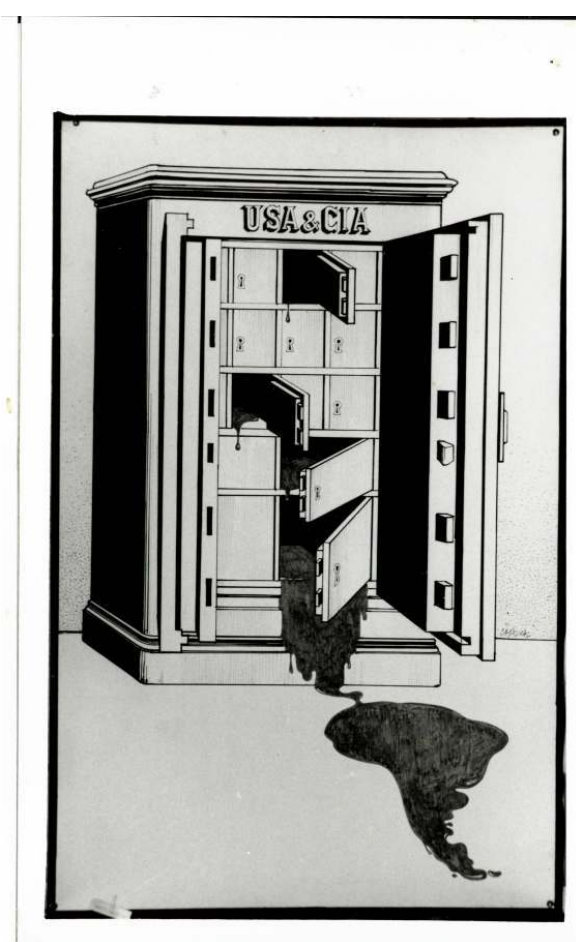


4 Algunos afiches en Amérique Latine non Officielle (1970) : dos provenientes de la exposición Malvenido Rockfeller (Archivo León Ferrari) y Non à la Biennale, portada del dossier que reunió en París proclamas relativas al boicot a la Bienal de San Pablo de 1969.

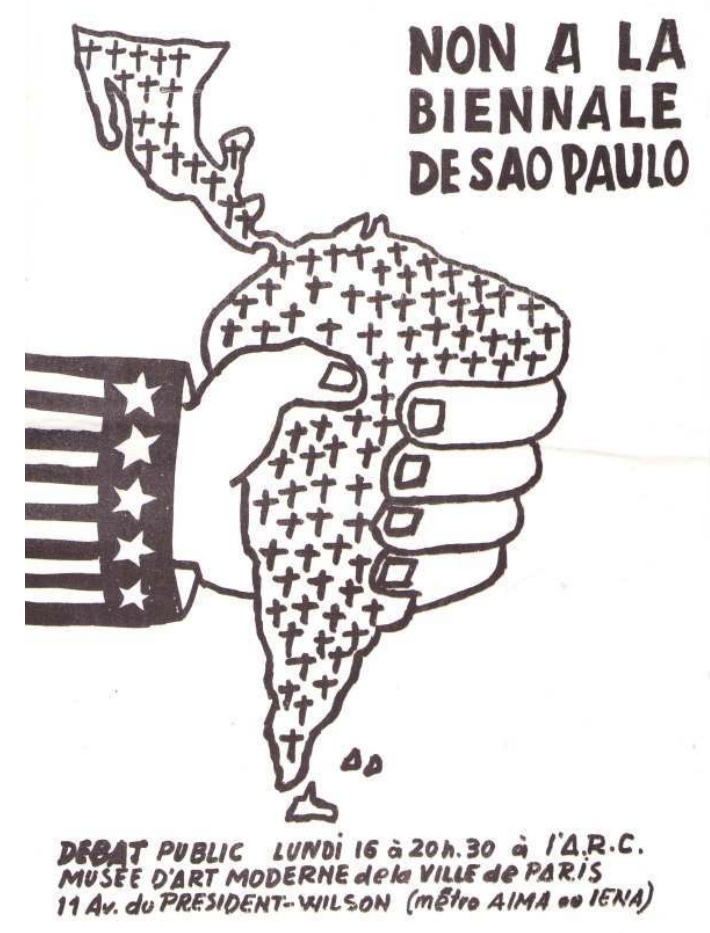

Amérique Latine non-officielle fue extranjera en varios sentidos. Una exposición organizada por artistas pero ajena al campo artístico, realizada en París pero dedicada a temas foráneos sobre los cuáles habían aportado información "grupos que viven día a día la lucha del pueblo para liberarse del neo-colonialismo" ". Además, en el contexto de la muestra se pusieron en circulación materiales llegados desde el exterior, producciones visuales cuya exhibición era restringida o estaba vedada en su lugar de origen. Por ejemplo, pudieron verse afiches de Malvenido Mister Rockefeller, la exhibición realizada en la Sociedad Argentina de Artistas Plásticos (SAAP) a fines de junio de 1969 que reunió carteles realizados por unos sesenta artistas en repudio a la visita porteña de Nelson Rockefeller, gobernador del estado de Nueva York enviado en "misión presidencial" por Richard Nixon. En la exhibición parisina también se proyectó La hora de los hornos (1968), el documental dirigido por Pino Solanas que había sido exhibido en Tucumán Arde.

\section{Lea Lublin, entre París y el Tercer Mundo}

Residente en Francia desde 1964, de los artistas argentinos de París Lea Lublin fue la que mayor actividad desarrolló en Sudamérica. Su presencia en la agenda artística local se intensificó entre 1969 y 1972, cuando vivió en Buenos Aires. Y suele pasarse por alto que por lo menos hasta 1972, además de poner en relación la exploración del estatus de las imágenes con la crítica institucional, buena parte de sus proyectos también articularon las escenas artística y política latinoamericanas con la ciudad de París. Sus estadías en una y otra ciudad se combinaron junto con sus intereses estéticos y políticos en un vaivén artísticamente productivo entre Europa y América. 
En 1965 Lublin inició una serie de obras que llamó Ver Claro y basó en la reutilización y el montaje de imágenes emblemáticas de la historia del arte o de la historia a secas, cuya percepción modulaba mediante su dispositivo de exhibición : una suerte de vitrina con limpiaparabrisas y peras de goma para echar agua. Al igual que Julio Le Parc, en entrevistas y textos Lublin se refería a la necesitad de desmitificar el arte y la cultura. Pero el cinetismo exploraba el trabajo colectivo y la producción múltiple con vistas a abolir el estatus tradicional (entre aurático y elitista) del artista y su obra (PLANTE, 2010). En cambio, en el trabajo de Lublin el ímpetu por descentrar el sentido común se detenía en las imágenes como artefactos. Esto es, en los modos en que ciertos emblemas encarnaban 'mitologías': imágenes que condensaban tanto tradiciones del ver y el representar, como un conjunto de sentidos estéticos e históricos estabilizados. A diferencia del arte cinético, que confiaba ese rol desnaturalizador del sentido común a la alteración de la percepción visual y háptica, Lublin trabajaba sobre una iconografía de alta visibilidad en la cultura urbana de los años sesenta.

\section{Lea Lublin, Recuerdo histórico bajo limpiaparabrisas, 1965}

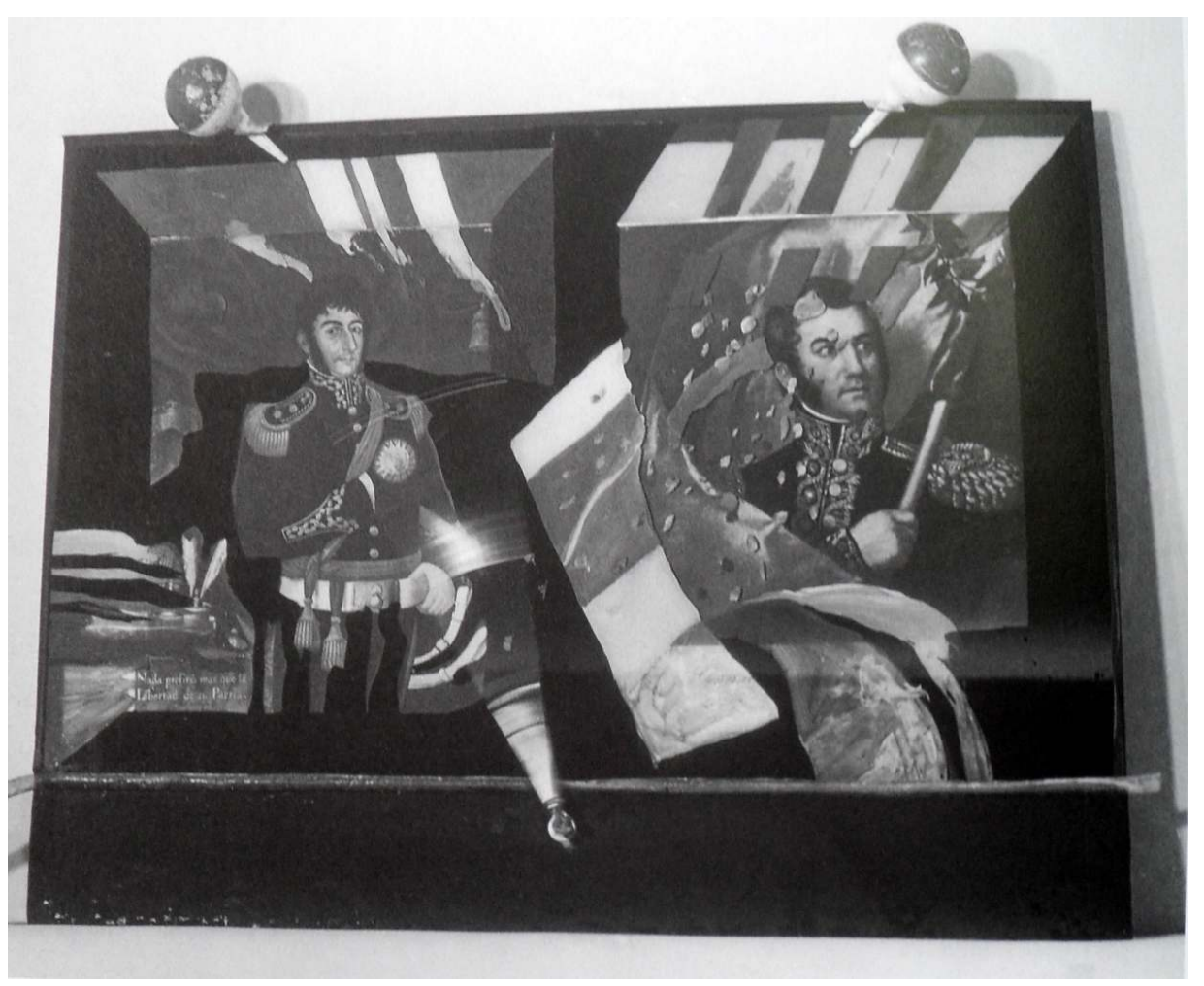

serie Ver Claro

Una de las obras de la serie Ver Claro se tituló Recuerdo histórico bajo limpiaparabrisas, y fue exhibida en 1965 en la galería La Ruche de Buenos Aires. Detrás del vidrio colocó, a la par, las reproducciones de dos retratos bien diferentes de José de San Martín, el libertador americano: uno de los realizados hacia 1818 en Chile por el pintor mulato peruano José Gil de Castro; y un segundo retrato de mediados del siglo XIX, atribuido a una maestra de dibujo de la hija del prócer y pintado en Bruselas (MALOSETTI, 2009). Las reproducciones de esos cuadros se exhibían en tanto representaciones comparables con sus respectivas características materiales y convencionales; como artefactos visuales que provocan respuestas más emocionales que intelectuales tales como, por ejemplo, identificarse con 
cierta pertenencia regional. Por supuesto, la obra de Lublin operaba con una cultura visual específica: puesto que se exhibía en Buenos Aires, se preveía un espectador familiarizado con el retratado y sus representaciones canónicas.

A la hora de montar una de estas obras en el Salón de Mayo parisino de 1966, Mitos, la artista hizo otra selección iconográfica pertinente. A partir de un dispositivo similar, Lublin seleccionó reproducciones de cuadros y fotografías de una serie de próceres y emancipadores latinoamericanos: el Tiradentes, O'Higgins, Saavedra, Belgrano, San Martín, Martí, Sarmiento, el Che Guevara y Fidel Castro. La artista resumía la invitación de Ver Claro en estos términos: "venga a ver de otro modo lo que usted ya ha visto". ${ }^{10} \mathrm{En}$ efecto, se trataba de una selección que incorporaba íconos de alta visibilidad pública en esos años y coincidía en buena medida con la lista de héroes independentistas evocados algunos años más tarde en la mencionada Amérique Latine non-officielle. Pero Lublin no solo abordaba las representaciones en su carácter referencial, sino también en su espesor. Asumía el poder que investía a esas imágenes, incluso (o tal vez especialmente) en las reproducciones masivas. Si bien su trabajo procuraba salirse del encantamiento que pueden producir los íconos, de algún modo también los amparaba de la industria cultural o la moda latinoamericana que amenazaba vaciarlos de sentido a fuerza de reproducirlos al infinito.

En 1970, la artista inició su "Proceso a la imagen" y lo definió como "desciframiento activo de los elementos que constituyen el sistema de la representación". ${ }^{11}$ El dispositivo preferencial para descentrar un modo aprendido de mirar (y de creer en) las imágenes era la proyección de pinturas clave de la historia del arte sobre cortinas de tiras plásticas transparentes que el visitante debía atravesar a su paso. Este contexto 'participativo' requería nuevas prácticas de lectura de esas imágenes por parte del público, se evitaba la contemplación y se proponía una posición más activa para el visitante. Pero esto no implicaba indagar en el sentido histórico o la genealogía de esas obras de arte tomadas de distintos momentos de la historia. La intención era poner de relieve cómo esas imágenes se naturalizaban o revelaban sus características intrínsecas y las narrativas sobre las cuales se montaban (RICCARDI, 2010).

Con el ambicioso proyecto Cultura: dentro y fuera del museo, montado a fines de 1971 en el Museo el Nacional de Bellas Artes de Santiago de Chile, Lublin redobló su apuesta. Según la artista, se trataba de una labor interdisciplinaria cuyo objetivo era "plantear los interrogantes sobre la representación del mundo y la constitución de los diferentes lenguajes plásticos y/o visuales que lo transmiten". ${ }^{12} \mathrm{Y}$ en última instancia, "señalar los mecanismos que mantiene ocultos la "cultura". ${ }^{13}$ Proponía entonces un abordaje vivencial y una reflexión activa sobre la circulación simultánea de, por un lado, las producciones de la industria cultural (que representaban los procesos sociales, aquello que ocurría fuera del museo). Y por otro lado, los procesos intelectuales y técnicos del conocimiento y del arte, propios de la esfera interna del museo. Como veremos, la obra tendía tanto a remarcar las diferencias entre el interior y el exterior, como a generar porosidades en los límites del museo.

Durante los años sesenta, las instituciones culturales resultaron más un campo de problemas que un mero ámbito de exhibición. Hacia fines de la década, se multiplicaban las propuestas artísticas que las señalaron como agentes de reproducción de las relaciones de poder que articulaban los diversos sectores sociales. Las tácticas utilizadas abarcaron desde el boicot y la autoexpulsión de las instituciones del arte, hasta el desmenuzado de dispositivos de exposición dentro de sus salas. Cultura: dentro y fuera del 
museo se ubicaba entre estas críticas, pero articulaba además un eje geopolítico. Lo que ocurría fuera del Museo Nacional de Bellas Artes de Santiago en 1971 era inédito en la historia mundial: el acceso al socialismo por la vía democrática.

La artista pasó tres meses en Chile, pero a pesar del esfuerzo (había conseguido la cooperación de instituciones locales como Chile-Films, canales de televisión y Escuelas de Bellas Artes) la obra solo duró unos pocos días. De cualquier modo, la prensa se hizo eco del evento difundiendo las explicaciones que ella formulaba: "Dentro está lo clasificado, lo ordenado, lo congelado. La calle es un juego físico, dentro hay un juego intelectual; afuera está la realidad, en el interior la representación de la realidad". ${ }^{14}$ Para Lublin la representación no era menos importante que la realidad. La simbolización era un proceso sustancial en la aprehensión de esa realidad. De hecho, estaba convencida de que los cambios socio-económicos promovidos por el régimen de Salvador Allende no resultarían duraderos o completos sin una revolución cultural. Esta obra tendía así lazos estrechos con el contexto local. Pretendía nada menos que contribuir al proceso político chileno puesto que la cultura tenía un rol fundamental en la base misma de las concepciones políticas.

En ese lugar -el Chile de Allende- las instituciones artísticas estatales podían representar obstáculos para el cambio social, pero también (y más que en ningún otro lugar) constituir instrumentos para posibilitarlo. Desde ese lugar específico de enunciación, Cultura: dentro y fuera del museo también establecía conexiones con la historia del arte, las producciones más recientes del arte contemporáneo, y con las experimentaciones previas de la misma artista. Apostando al potencial del museo para incidir en los procesos de simbolización y representación, Lublin volvió a utilizar una gran variedad de recursos y dispositivos.

\section{6 : Lea Lublin, Cultura: dentro y fuera del museo (1972)}
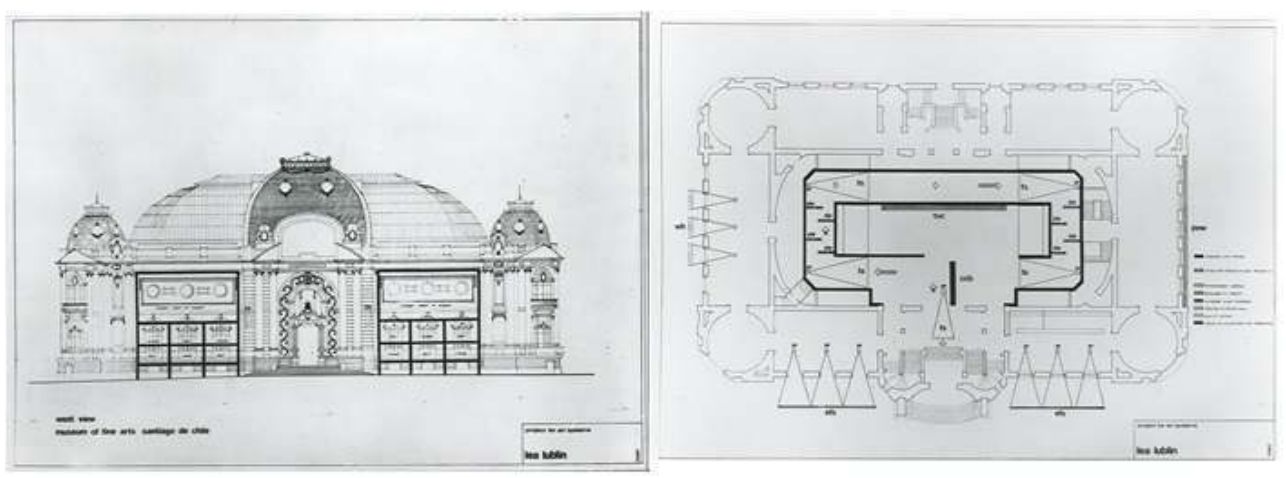

Plano de la fachada del Museo Nacional de Bellas Artes, Santiago de Chile y Planta del Museo Nacional de Bellas Artes, Santiago de Chile.

La sección "Fuera del museo" constó de tres partes ${ }^{15}$ : la fachada del elegante edificio de 1910 funcionó como el "Muro de los medios de comunicación masiva", sobre el que se dispusieron pantallas traslúcidas para proyectar desde el interior del museo materiales audiovisuales acerca de los hechos más notables ocurridos en Chile durante los meses anteriores. En la fachada Sur se alzaba el "Muro de la historia", con dos pantallas sobre las que se proyectaban imágenes relativas a las figuras clave de la historia chilena, y sus conexiones con otras figuras históricas de América latina. En la fachada lateral Norte, la superficie blanca del "Muro de la expresión popular" era renovada a diario para que el 
público realizara dibujos o grafitis, que se filmaban y se transmitían en televisores ubicados dentro de las salas del museo.

La sección "Dentro del museo" también se organizaba en tres capítulos. Un recorrido ofrecía al visitante información sobre las nociones y rupturas conceptuales más importantes del arte y las ciencias desde mediados del siglo XIX, información articulada por medio de diagramas que Lublin llamaba "Paneles de producción interdisciplinaria". Por ejemplo, el panel relativo a la teoría lingüística unía con flechas los nombres de Sausurre, Whitney, Harris y Chomsky junto con explicaciones sintéticas. Para armar estos esquemas sinópticos, la artista contó con la colaboración de varios especialistas en física, ciencias sociales, lingüística, filosofía, psicoanálisis, artes plásticas y experiencias ópticoperceptuales (el argentino residente en Francia Eliseo Verón, el brasileño instalado en Chile Mario Pedrosa y el chileno Carlos Martinoya, entre otros).

Según indican los planos, los Paneles se alternaban con una serie de cortinas de tiras translúcidas sobre las que se proyectaban diapositivas de una selección de pinturas desde el Impresionismo hasta 1971. El espectador debía atravesarlas para seguir el recorrido, mientras escuchaba un montaje sonoro de música correspondiente a los mismos períodos. Aquí es interesante notar que Lublin tuvo que colocar carteles indicando a los visitantes que traspasaran esas imágenes proyectadas porque éstos tendían a quedarse frente a ellas, mirando. En el centro de la sala, un circuito cerrado de televisión ofrecía la transmisión directa de las situaciones que ocurrían fuera del museo, en sus tres Muros. Se exponían registros -mediados por dispositivos tecnológicos- de manifestaciones anónimas: murales callejeros y grafitis.

31 Estas primeras experimentaciones de Lublin con la penetración de las imágenes han sido asociadas con posterioridad por algunas investigadoras a una perspectiva de género, en el sentido de la representación o la posición respecto de las diferencias entre varones y mujeres. ${ }^{16}$ Pero si bien la artista efectivamente articuló una crítica de género en obras posteriores, pareciera más ajustado afirmar que en estas obras realizadas mientras estuvo instalada en Buenos Aires (de 1969 a 1972), la propuesta de penetrar la imagen funcionaba más como crítica cultural que de género. Recordemos que ya en 1966 los artistas varones del Groupe de Recherche d'Art Visuel ${ }^{17}$ habían construido unos Penetrables de tubos de goma, denominación y dispositivo que Jesús Rafael Soto retomaría al año siguiente y haría más conocidos. Esas propuestas de corte universalista (dirigidas a todos y todas en tanto pares) iban ligadas a la intención de desestabilizar la percepción de lo cotidiano y generar una participación activa del espectador. Y los proyectos de Lublin parecen ir en este mismo sentido, con la diferencia que la artista no abandonaba la figuración sino que ponía a prueba la historia del arte en tanto actividad paradigmática en la estructuración y los usos de la representación visual.

La proyección retroactiva de un punto de vista feminista tiende a invisibilizar el sentido del lugar que su trabajo revisó desde mediados de los años sesenta hasta mediados de la década siguiente. Un lugar geográfico y de enunciación, a partir del cual se articularon sentidos relativos a las potencias del Tercer Mundo y las distancias (y cercanías) con la cultura europea. Cultura : dentro y fuera del museo fue sitio-específica : su sentido resulta indisociable del lugar en que se realizó. La fortuna crítica de esta obra estuvo signada por el hecho de que estos temas perdieron interés público en Europa (y obras como esta resultaron inviables dentro del nuevo panorama político latinoamericano). Con la militarización de los gobiernos a partir de 1973, ${ }^{18}$ Latinoamérica se disipaba en tanto idea culturalmente productiva y ese lugar de enunciación se fue desvaneciendo. 
En 1972, Lea Lublin regresó a París y comenzó a trabajar en una nueva versión de Dentro y fuera del museo. Solo en 1974 logró desarrollar en la galería Yvon Lambert una versión limitada a la sección del discurso sobre el arte. Más allá de los motivos coyunturales por los cuales no concretó la versión más ambiciosa de su proyecto, parece poco viable que una obra como la realizada en Chile pudiera llevarse a cabo en un museo parisino. Bernard Teyssèdre argumenta con ironía que no imagina al Musée National d'Art Moderne cediendo uno de su muros exteriores para que la gente se expresara mediante grafitis acerca del régimen de Pompidou, ni para que se proyectaran diapositivas sobre las luchas revolucionarias en Francia. ${ }^{19}$ Más allá del tono sarcástico y poco explicativo de Teyssèdre, el crítico señala cierta asimetría entre los museos de una y otra ciudad. Si bien las instituciones chilenas o argentinas también fueron sometidas a críticas por los artistas locales, no eran del todo analogables a las francesas. La obra de Lublin fue sensible a esas asimetrías entre Sudamérica y Europa, y las incorporó a su programa desocultador de la retórica de la cultura.

\section{Antonio Seguí, paisajes a distancia}

En una entrevista de enero de 1970 realizada durante una visita a Buenos Aires, Antonio Seguí contaba que en París se preparaba una "contraexposición" para contrarrestar la información oficial llegada de los países de América Latina: "En el barrio de Les Halles nos han cedido un galpón inmenso, donde un grupo de latinoamericanos pensamos presentar este acontecimiento multimedia con intención didáctica". ${ }^{20}$ Se refería, con seguridad, a Amérique Latine Non-officielle. Sin embargo, no participó de esa exhibición. Seguí recuerda que "a comienzos de los setenta Julio [Le Parc] se metió en cosa de mucho sindicato, reuniones. Yo les rajé. Julio hacía unos tipos torturados". ${ }^{21}$

Las diferencias entre estos dos artistas fueron políticas, por supuesto, pero también parecen haber mediado divergencias estéticas. Con el arte cinético se podían inventar imágenes potentes e intervenir en la percepción del nutrido público de sus exposiciones, pero no era viable transmitir ideas o críticas políticas precisas. Artista cinético, Le Parc dedicó parte de su tiempo a lo que podría denominarse un arte de protesta. Como vimos, organizó exhibiciones y elaboró imágenes que denunciaban el 'subdesarrollo' de Latinoamérica, la persecución política y el uso de la violencia contra la población civil por parte de los Estados nacionales de la región. En cambio, un artista de la figuración crítica como Seguí no veía necesario un salto cualitativo de ese tipo. Las referencias burlonas a militares y burgueses ya aparecían en sus obras de comienzos de los años sesenta. Es el caso, por ejemplo, de Autorretrato de las vocaciones frustradas (1963). 


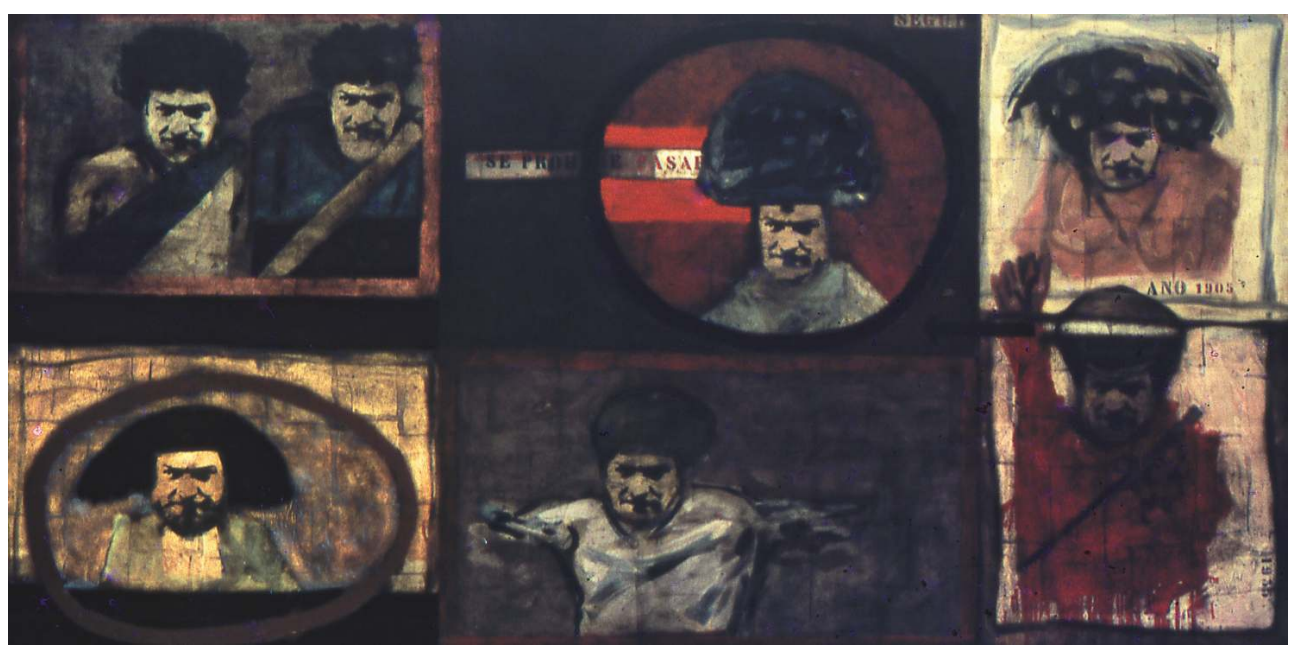

óleo, esmalte sintético, collage y betún de judea sobre tela, 200 × 400 cm.

Esta pintura de gran formato resulta una pieza clave en la trayectoria de Seguí, tanto por el giro que implicó en su pintura como por el lugar que ocupó en su inserción en el mercado de arte y en el desarrollo de su carrera profesional. Si bien hacia 1962 Seguí había abandonado una abstracción lírica de tonos terrosos, con obras como esta definió una serie de cambios que lo vincularon con las nuevas figuraciones: aclaró su paleta, aligeró la carga matérica, delineó las formas con mayor nitidez e incorporó letras, números, flechas y tachados a su iconografía. En 1963, el mismo año en que participó del Premio Nacional organizado por el flamante Centro de Artes Visuales del Instituto Torcuato Di Tella, en Buenos Aires, Jorge Romero Brest promovió la adquisición de Autorretrato de las vocaciones frustradas por parte del instituto. Esta venta por un monto considerable le permitió a Seguí planificar una estadía de tres o cuatro meses en el extranjero. En octubre viajó a París y en la capital francesa su profesionalización se aceleró.

Este pintor cordobés fue uno de los artistas argentinos de París que con mayor rapidez obtuvieron reconocimiento y, sobre todo, ventas. Apenas llegado a Francia, en 1963 expuso en la Bienal de París la serie de Felicitas Nahón que había pintado en Buenos Aires a partir de la intervención de fotografías familiares antiguas recreadas alrededor de esta dama de sociedad ficticia, y vendió 13 de las 15 pinturas exhibidas. ${ }^{22} \mathrm{~A}$ fines de ese año el Musée d'Art Moderne de la Ville de Paris (MAMVP) adquirió otra de las obras de esta serie, Mi Mujer ${ }^{23}$. En 1964, Seguí realizó sus dos primeras exposiciones individuales en sendas galerías parisinas de renombre, Jeanne Boucher y Claude Bernard, ${ }^{24}$ con muy buen resultado comercial. Una nota sobre los argentinos de París de la revista Confirmado utilizaba el siguiente epígrafe para la fotografía del artista: "Pintor Seguí : 26 cuadros vendidos en la primera exposición, y un contrato para la producción anual de 70 cuadros". ${ }^{25} \mathrm{El}$ mismo Seguí afirma que esos fueron años de bonanza y diversión; en el taller de las afueras de París compartido con Rómulo Macció y Lea Lublin organizaban asados y fiestas : "ganaba tanta guita que no sabía qué hacer". ${ }^{26}$

Autorretrato de las vocaciones frustradas parece constituir además un punto de inflexión en la concepción de sí mismo en tanto artista. Hacer del arte una profesión implicaba declinar otras vocaciones. Esta pintura de gran formato nos muestra el rostro de Seguí 
repetido siete veces -la misma fotografía fotocopiada y adherida- sobre la superficie de la tela dividida en seis recuadros. El artista caricaturizó su propia imagen agregando rasgos $\mathrm{y}$ vestimentas con pinceladas rápidas. Las inscripciones con letras de molde ofrecen pistas para dilucidar algunas de esas inclinaciones dejadas de lado. En el ángulo superior derecho se ve al pintor con una melena voluminosa y la inscripción "año 1905". Si tenemos en cuenta que mientras estudiaba abogacía en Córdoba, Seguí militó en la juventud frondizista, es posible pensar que la fecha alude a la sublevación organizada ese año por la Unión Cívica Radical con Hipólito Yrigoyen -el peludo- a la cabeza. En el ángulo inferior izquierdo también predominan el rojo y el blanco, los colores de la UCR: se muestra a Seguí como militar, con gorra y espada. Al lado puede leerse "1935", el año en que la UCR volvió a participar de las elecciones luego de años de política abstencionista durante el gobierno de facto de Agustín P. Justo. Respecto de su vínculo con la actividad política, años más tarde Seguí aclaraba:

A mí me encanta la política. Pero tuve que elegir, entre la pintura y la política y me quedé con la pintura. [...] Entre el 55 y el 57, mientras estudiaba abogacía, fui presidente de un Comité de Sección y después de la Juventud de Córdoba del Frondizismo. Pero cuando ganó las elecciones Frondizi, me abrí. Siempre pensé que la pintura y la política son dos cosas que no van bien juntas. Por otra parte, así como no entendí cómo funcionaba el medio artístico en Buenos Aires, tampoco entendí cómo funcionaba el medio político ${ }^{27}$.

Seguí evitó alusiones directas a programas políticos que sujetaran el tono lúdico y mordaz de sus imágenes. Pero esto no significó que se mantuviera indiferente a los acontecimientos parisinos de fines de los años sesenta. Su nombre aparece, por ejemplo, en una exposición y venta de obras en apoyo a los "militantes de la libertad en Brasil", organizada por la Galerie du Dragon, la misma que había impulsado la producción de afiches litográficos firmados durante el Mayo francés, iniciativa en la que Seguí también participó. ${ }^{28}$

41 A su vez, la escena política tampoco fue indiferente hacia este pintor. El episodio más evidente en este sentido tal vez haya sido la reunión de 1972 en París con Juan Domingo Perón, que compartió con Le Parc y Nicolás García Uriburu. La política nacional estaba ritmada por la normalización de los partidos políticos, los contactos con Perón en España $y$, en especial, por las tensiones entre el peronismo y la administración del presidente de facto Alejandro A. Lanusse en relación con el regreso y candidatura presidencial de Perón. ${ }^{29}$ Por más que Seguí hubiera elegido la pintura a la política, la primacía de la política de esos años ${ }^{30}$ (y los propios intereses del artista) lo confrontaban con la actualidad nacional, aun en París.

En la entrevista de 1970 mencionada al comienzo de este apartado, Seguí se refería a sus pinturas más recientes, "enormes tarjetas postales -óleos de 2 x 2 metros- representando paisajes 'turísticos' de Córdoba, animados por sutiles detalles desconcertantes". ${ }^{31}$ La serie se componía aproximadamente de una decena de paisajes cuyos títulos refieren a diversas localidades de la provincia de Córdoba: Paisaje de Villa Allende (1967), Sierras de Córdoba (1968), Mendiolaza (1968), Paisaje serrano (1968), Capilla del Monte (1968), El Zapato (1969), Los Mogotes (1969), Lago San Roque (1969), Villa del Lago (1969), Paisaje serrano (1969) y Parque Siquiman (1969). ${ }^{32} \mathrm{El}$ tema no era una novedad, pues algunas de sus óleos sobre tela y madera recortada de 1966 también aluden con claridad a la misma región argentina: Bucólico Serrano, De Córdoba con amor y Saldán es negro también aluden con claridad a la misma región argentina. Pero el tratamiento de las telas realizadas entre 1967 y 1969 presenta características particulares: la ausencia de figuras y la apropiación del 
imaginario turístico, en tanto celebración de lo natural diseñada para ofrecer autenticidad. Esta serie está compuesta por dos tipos de paisajes: imágenes que remedan tarjetas postales cordobesas y vistas muy sintéticas que podrían referir a casi cualquier lugar pero se anclan en esta provincia a través de sus títulos, inscriptos sobre las telas con tipografías publicitarias. Aquí es fundamental señalar que estos paisajes fueron realizados en París y no se exhibieron nunca en Argentina. Se trata de algo así como paisajes hechos a distancia, imágenes que no refieren a América Latina sino a un lugar más específico, la provincia de origen del pintor: Córdoba. En este sentido, si bien utilizan las postales e imágenes tipificadas de la industria del turismo, proponen una mirada hacia Latinoamérica ajena a los lugares comunes del paraíso político o natural.

\section{9: Antonio Seguí, El Zapato (1969)}

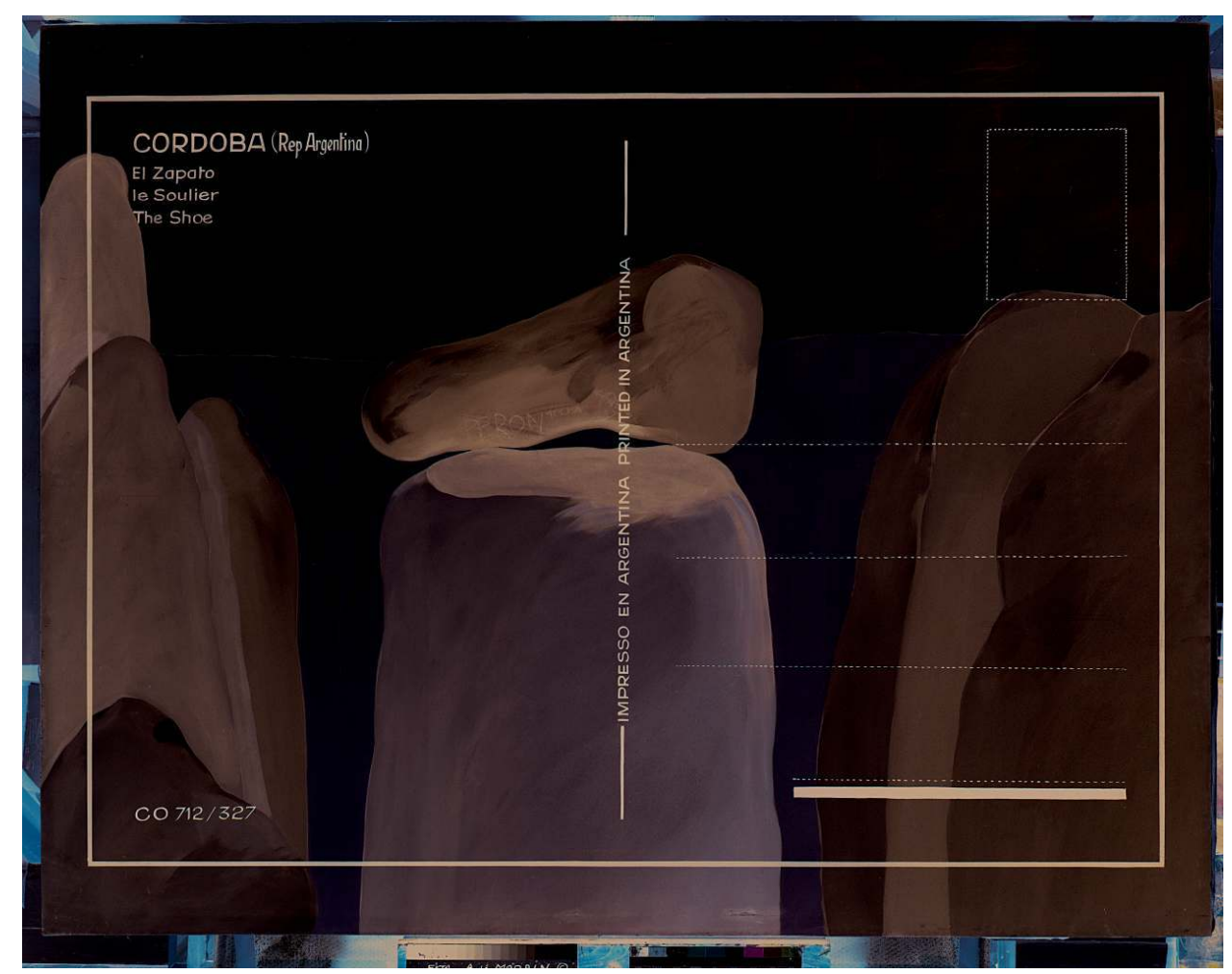

óleo sobre tela, 200 × 250 cm

El Zapato consiste en una vista de uno de los atractivos turísticos más publicitados de la pequeña localidad de Capilla del Monte: una gran piedra tallada por el viento que recuerda, por su forma, un calzado. Esta tela de dos metros y medio reproduce el reverso de una postal superpuesto a la vista de esta piedra. Una serie de inscripciones completan la información sobre la tarjeta postal: en el ángulo superior izquierdo, el lugar representado; y como parte de la línea que divide al medio la gran tela, "Impresso en Argentina. Printed in Argentina". Sobre el monumento representado se ven otras inscripciones, como las que se pintan sobre rocas y estatuas: en la zona inferior del zapato, cerca del pedestal, al lado de un corazón, es posible leer "Perón".

Según su testimonio, Seguí visitó la Argentina veinte días después del Cordobazo, la manifestación liderada por los renovados sindicatos cordobeses que, represión policial mediante, se redefinió como un levantamiento popular y se adueñó de la ciudad el 29 de mayo de 1969. Seguí pintó El Zapato ese mismo año. Por supuesto, la pintura no representa 
el Cordobazo. Pero sí parodia las imágenes tipificadas de las bondades turísticas de esa provincia cuyo perfil productivo y sindical se había modificado durante la presidencia de Arturo Frondizi con el establecimiento de industrias, principalmente de fabricación de automotores. En una entrevista posterior, en referencia a esta serie de paisajes Seguí explicaba a su interlocutor francés que había vivido en Córdoba hasta los 16 años. Sobre su lugar de origen, aclaraba: "La mayor parte de los extranjeros en Argentina no conocen Córdoba. Cuando piensan en la Argentina, piensan en Buenos Aires. [...] Córdoba es maravillosa, llena de paradojas". ${ }^{33}$ Esta serie de pinturas juega con la idea sesgada (o nula) que podía tenerse en Europa de esta provincia y parece poner en obra una mirada distanciada hacia el entorno cordobés.

\section{0: Antonio Seguí, Paisaje serrano (1969)}

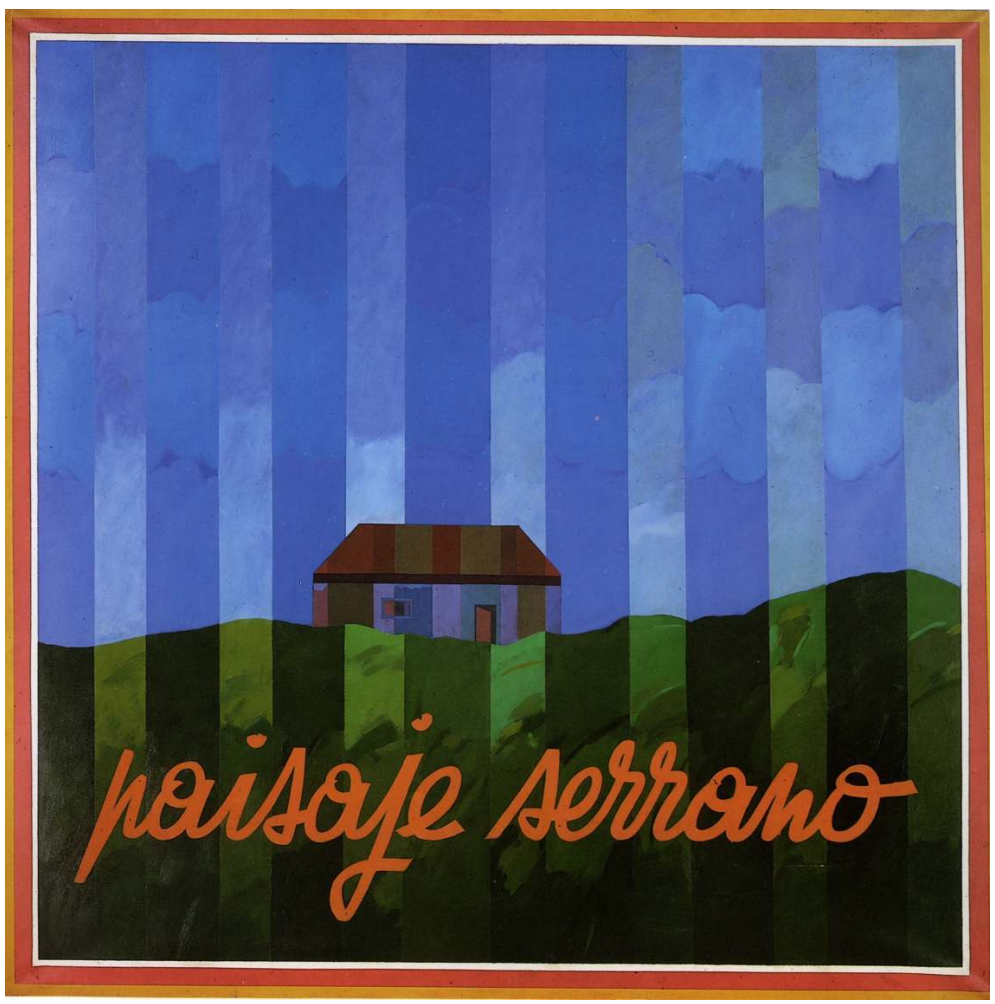

oleo sobre tela, $194,9 \times 194,9 \mathrm{~cm}$

Se trata de una mirada que, o bien formatea las vistas como imágenes turísticas concebidas para hacer ver un lugar a la distancia -tarjetas postales- ; o bien describe un paisaje sin marcas de lugar, indiferenciadas panorámicas campestres sólo interrumpidas por alguna casita sin rasgos particulares. Al mismo tiempo, unas franjas verticales dadas por matices o valores diferentes del color interfieren en la transparencia de la representación y opacan una percepción ilusionística. En estas pinturas, la distancia respecto del referente parece ampliada al punto casi de disiparse las posibilidades de visibilidad. Sólo la palabra, al nombrar lugares específicos en los títulos e inscripciones, anuda lazos a pesar de la lejanía. 


\section{Mapas y coloraciones de Nicolás García Uriburu}

La obra de García Uriburu presenta otras modulaciones de la distancia respecto del paisaje latinoamericano. Este artista implementó, en simultáneo, la intervención directa del entorno en el ciclo de coloraciones iniciado en Venecia en 1968, y una perspectiva alejada en los mapas de Sudamérica realizados a partir de 1970. García Uriburu residía en Francia desde fines de 1965, luego de haber ganado una de las recompensas del Premio Braque.

En marzo de 1970, el crítico francés Pierre Restany organizó la exposición Art Concepts from Europe en la Galería Bonino de Nueva York. Convocados a remitir una "idea performante", unos cuarenta artistas (Walter De Maria, Bernard Borgeaud, Gina Pane, Joseph Kosuth y Dennis Oppenheim, entre ellos) enviaron cartas, álbumes, planos, dibujos o comunicaciones telefónicas grabadas. García Uriburu participó con un proyecto de coloración del río Hudson en Nueva York. Esta idea evolucionó rápidamente hacia el Proyecto intercontinental de coloración de las aguas. La intención era verter fluoresceína (la misma sustancia inocua utilizada en Venecia que al contacto con el agua vira a un verde fluorescente) en cuatro ríos : East River, Sena, Gran Canal de Venecia y Riachuelo.

\section{GREEN NEW YORK

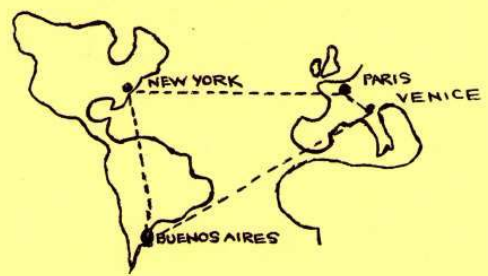

INTERCONTINENTAL PROJECT OF WATERS ENVIRONMENT

May 17 - Coloration of the East River, New York

June 15 - Coloration of the Seine River, Paris

June 27 - Coloration of the Canals, Venice Bienal

July 15 - Coloration of the Riachuelo River, Buenos Aires

An artist can colored and transform nature in a plastic point of view.

The color is no toxic.

The seventies are open.

\section{Uriburu}

fotocopia sobre papel amarillo. 


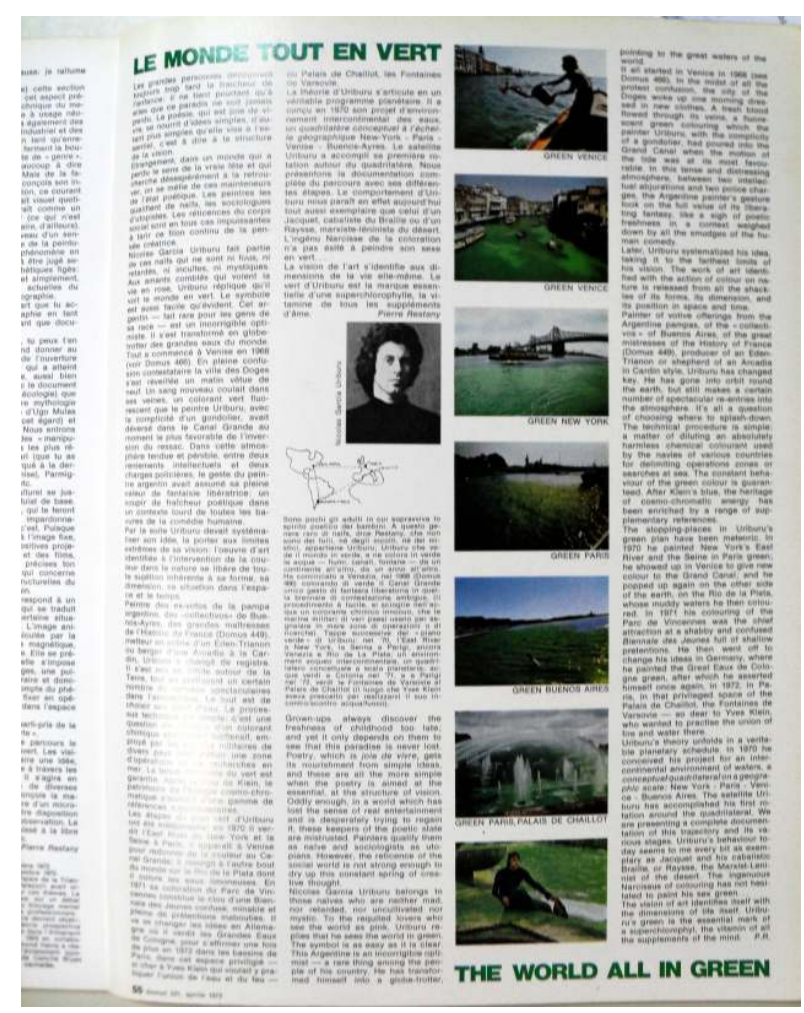

Domus n. 521, avril 1973, p. 55.

En el curso del año 1970, García Uriburu llevó a cabo su ambicioso plan con algunas modificaciones. El artista llegó a Nueva York en mayo, dos meses después de la exposición en Bonino y a pocos días de celebrado, por primera vez, el Día de la Tierra en defensa del medioambiente. El 26 de mayo García Uriburu coloreó el East River a la altura de la calle 61, en presencia del crítico británico Lawrence Alloway, el director del Guggenheim Museum Thomas Messer, el galerista John Weber y el artista y crítico del Village Voice John Perrault. ${ }^{34}$ Poco después, García Uriburu regresó a París y el 15 de junio intervino el Sena desde el Pont de la Concorde. Ese caso era más simple que Nueva York o Venecia porque el agua corría sólo en un sentido y no era necesario estudiar las mareas. En Venecia, el 27 de junio se encontró con Memmo, el gondolero pintor que lo había asistido para teñir el Gran Canal en 1968, y disolvió en el agua 60 kilos de fluoresceína, el doble de lo utilizado en la primer experiencia veneciana. En julio, coloreó el Río de la Plata frente a la usina eléctrica de la Compañía Italo-Argentina de Electricidad ubicada en Puerto Nuevo. En ningún caso tuvo financiación ni permiso alguno. Las coloraciones fueron, en este sentido, acciones relámpago que implicaban cierto riesgo frente a las autoridades.

En un texto de 1974, Restany afirmaba que si en Buenos Aires García Uriburu había sido un artista pop, en París había transmutado en "arcadiano". ${ }^{35}$ El crítico se refería a la exhibición en el Musée Galliéra, centrada en el antagonismo entre la naturaleza y la civilización. Para el artista argentino se trataba de una oposición que tenía cierto paralelo con el par Latinoamérica-Europa. García Uriburu lo expresaba con claridad:

La segunda etapa luego de la coloración de los ríos (a partir de 1968) East River, Nueva York; Sena, París; Gran Canal, Venecia ; Río de la Plata, Buenos Aires ; lagos y fuentes, toma un sentido más completo y político. La unión de los países latinoamericanos por las aguas de esos ríos -por límites fijados por los hombres- 
todo un continente unido por la Naturaleza. Los elementos agua-tierra-aire reserva del futuro en el continente latinoamericano. Es un arte a escala latinoamericana. ${ }^{36}$

13: Nicolás García Uriburu, Latinoamérica. Reservas naturales del futuro. Unida o sometida (1973)

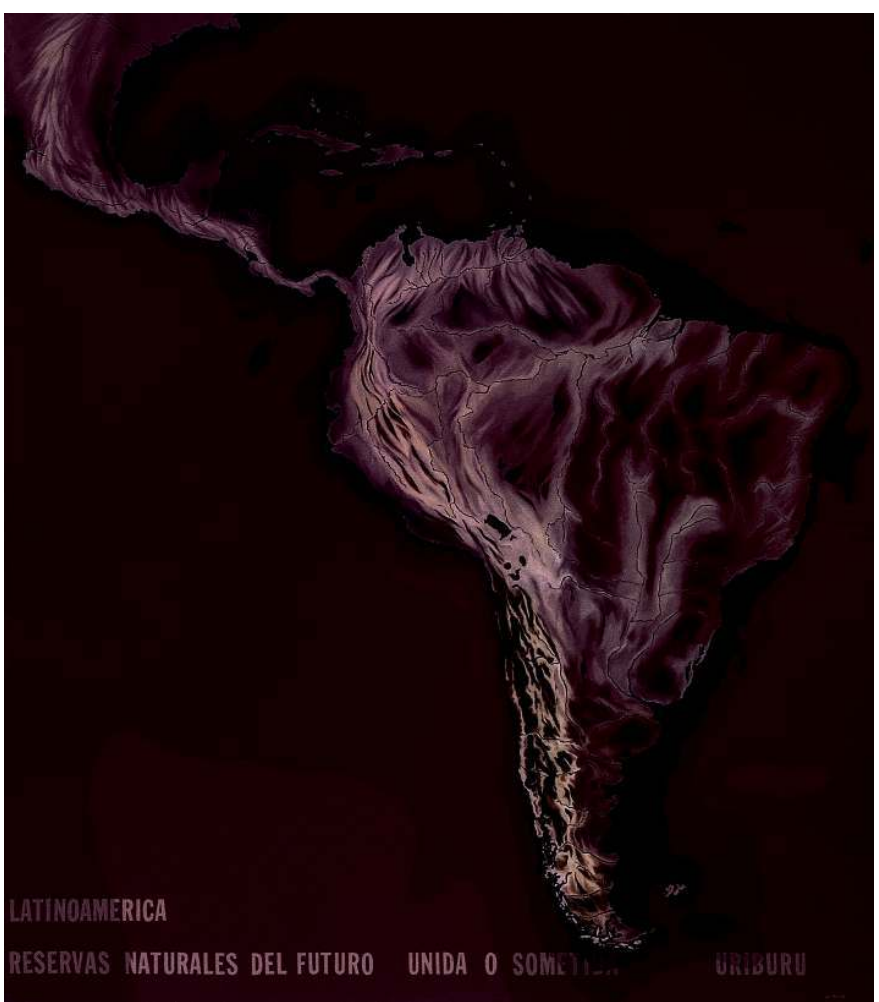

óleo sobre tela, 230 × 200 cm. Colección Fundación Nicolás García Uriburu.

El Proyecto intercontinental de coloración de las aguas fue contemporáneo a la serie de mapas de América del Sur. Estas cuatro pinturas de unos dos metros de lado representan, en tonos de verdes y azules, mapas de la región con sus cuencas hídricas y relieves geográficos pero sin divisiones políticas. Una de las telas lleva, en letras de molde, la leyenda "Latinoamérica. Reservas naturales del futuro. Unida o sometida". García Uriburu recreaba en clave ecológica la célebre máxima de Juan Domingo Perón: "La integración de la América Latina es indispensable: el año 2000 nos encontrará unidos o dominados". ${ }^{37} \mathrm{El}$ artista combinaba sus inquietudes respecto de cuestiones ambientales con la idea de una unidad latinoamericana y el anti-americanismo extendido en la época.

51 Si bien guardan cierta relación de analogía, los mapas funcionaban para García Uriburu (y tantos otros artistas) más como emblemas de Latinoamérica que como descripciones geográficas. De hecho, la reformulación del mapamundi realizada en 1974 por Arno Peters no parece haber sido utilizada por los artistas en esos años a pesar del sentido político que tuvo. Este nuevo atlas del historiador y cartógrafo alemán corrigió las distorsiones producto del despliegue bidimensional del globo y devolvió un aspecto más ajustado de las superficies de los diversos continentes. Pero si bien mostraba una Europa y una América más "reales", ese mapamundi resultaba menos reconocible que el propuesto por Mercator unos 500 años antes.

En un artículo de 1973, Néstor García Canclini hacía una crítica del llamado "arte ecológico" desde la teoría de la dependencia. 
53 Ni la explosión demográfica ni la contaminación son tema de interés directo para Argentina. Estamos poco poblados, y la tuberculosis de nuestros niños no se debe al "smog" sino a la "miseria" (esto vuelve aún más absurda, en países como el nuestro, la fuga a la naturaleza en busca de un espacio no contaminado para la creatividad artística). 38

14: Nicolás García Uriburu, Coloración de la Fuente del Trocadero (mayo de 1972)

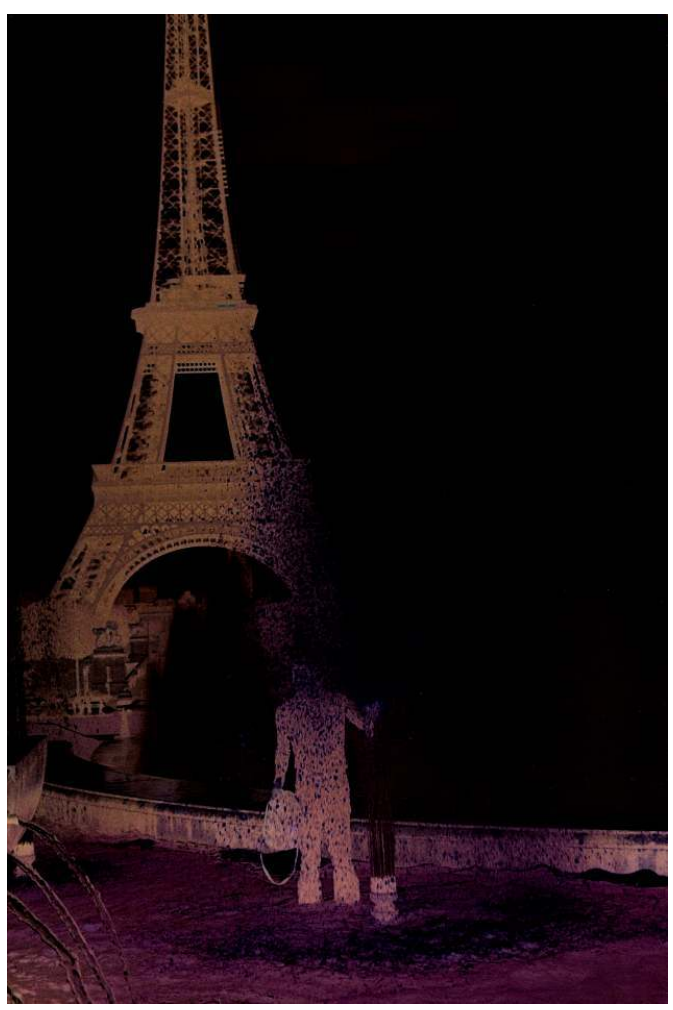

Fotografía, 100 x 75 cm. Colección Fundación Nicolás García Uriburu.

54 Pero a diferencia de los artistas del land art, la "fuga" de García Uriburu no había sido hacia la naturaleza sino hacia la "civilización”. El ciclo de las coloraciones siguió en 1971 en las fuentes del Parque de Vincennes, en las afueras de París, y en 1972, en las fuentes del Palacio Chaillot ubicado muy cerca de la Torre Eiffel. Tal como señalaba Restany, en París había adquirido una nueva perspectiva sobre los vínculos y desfasajes entre lo natural y lo artificial.

En 1973, García Uriburu reunió el ciclo de las coloraciones y mapas en una carpeta de estampas compuesta de seis serigrafías en blanco, negro y verde : la primera y la última son mapas físicos de América del Sur, la segunda tiene por tema la coloración de Venecia, la tercera ilustra con fotografías intervenidas el periplo del proyecto intercontinental de 1970, la cuarta reproduce el registro de la coloración del propio sexo realizada en 1971, y la quinta presenta un nuevo proyecto de "coloración vertical" : las cataratas del Iguazú. ${ }^{39}$ Latinoamérica tuvo un lugar clave en la antinomia entre naturaleza y civilización que García Uriburu ponía en imágenes. Si la región representaba el reservorio "verde” más importante del mundo, al menos para quienes tenían ciertas preocupaciones ecológicas, ${ }^{40}$ podría pensarse que colorear de verde las diferentes aguas del mundo no implicaba sólo señalar que se trataba del mismo líquido que las fronteras nacionales no podían contener. 
Colorear fuentes y ríos de ciudades europeas también era un modo metafórico de hacer presente ese verde latinoamericano en medio de la civilización.

Para pensar la obra de García Uriburu, Miguel Briante retoma los Viajes de varones prudentes (1658), escrito por Suárez Miranda y recogido por Jorge Luis Borges en su libro El Hacedor (1960). El texto se refiere a un imperio en el que el arte de la cartografía logró tal perfección que, en la pretensión de hacer mapas exactos llegaron a hacerlos de tamaño natural. Pero no finalizaron su tarea porque esos mapas terminarían por tapar el país (BRIANTE, 1998: 109). A comienzos de los años setenta, García Uriburu mapeaba el mundo en dos escalas simultáneas, una a distancia y otra por señalización in situ: representaciones cartográficas y coloraciones.

\section{La distancia y el lugar. Conclusiones}

57 En su análisis sobre producciones contemporáneas, María Clara Bernal repone a la familia y la comunidad como los lugares, simbólicos o afectivos, en los que la subjetividad diaspórica se localiza (BERNAL, 2005). La autora reformula en términos de no-lugar geográfico la idea de Latinoamérica como heterotopía. Pero si este abordaje viabiliza la conceptualización del arte de la región por fuera de los términos de la mentada "identidad", se trata de una óptica inviable para pensar estas y muchas otras producciones visuales de los años sesenta. Pues, por un lado, los artistas argentinos residentes en el extranjero se desenvolvieron en lugares concretos y desarrollaron una red de vínculos específicos que, como vimos, resultan centrales para analizar el sentido las obras. Pero además, en momentos de la emergencia internacional de América latina, el lugar geográfico resultaba insoslayable. El entramado cultural de estos años se repone más en los recorridos variados de obras, artistas, críticos y exposiciones, que en "nolugares". Se trata de flujos y apropiaciones simbólicas que tomaron forma como parte de un proceso de circulación cultural asimétrico.

Nuestra propuesta fue trabajar entre dos ciudades, a su modo metropolitanas: Buenos Aires y París. Frente a la imagen de Nueva York como la nueva sede del capitalismo (y del imperialismo), París aparecía en el horizonte internacional como una de las metrópolis que mayor eco se hacía del tercermundismo y, en este sentido, uno de los lugares para la resistencia a la avanzada norteamericana. La posibilidad de inscribir sus propios nombres en el panorama internacional de las artes entró en conflicto con el discurso sobre el auge de las "voces colectivas" del Tercer Mundo, que Frederic Jameson considera uno de los puntos que vertebran los años sesenta y que se traducía en reflexiones acerca de la "muerte del autor" (JAMESON, 1997). Durante estos años, América latina condensó nuevos sentidos ligados a un tercermundismo que festejaba esas "voces colectivas" que por primera vez se hacían escuchar sin la mediación de los intelectuales. Fue en este mismo período que los artistas latinoamericanos adquirieron mayor visibilidad. Pero en el ámbito cultural, esa "alteridad" que emergía en la escena internacional no siempre respondió a la expectativa de anonimato. Los artistas argentinos de París pretendían adquirir un reconocimiento equivalente al que hasta el momento había sido reservado a artistas de los centros. En otras palabras, hacerse un nombre. 


\section{BIBLIOGRAFÍA}

AA.VV., Más allá del boom: literatura y mercado. Buenos Aires, Folios, 1984.

BAYÓN Damián, Aventura plástica de Hispanoamérica. Pintura, cinetismo, artes de la acción (1940-1972), México, Fondo de Cultura Económica, 1974.

BERNAL María Clara, "Questions on Place and Space in Latin American Art", in Four Direction symposium, University of Essex, UK. Mimeo, 2005.

BRIANTE Miguel, “Utopías de la conciencia”, in Nicolás García Uriburu, Buenos Aires, MNBA, 1998. BOURG Julian, “Gender and '68 : tensions from the start", in From revolution to ethics. May 1968 and Contemporary French Thought, Quebec, McGill-Queen's University Press, 2007, pp. 179-186. CASULLO Nicolás, París 68. Las escrituras, el recuerdo y el olvido, Buenos Aires, Manantial, 1998. CLIFFORD James, Itinerarios transculturales, Barcelona, Gedisa, 1999.

CHONCHOL Jacques y MARTINIÈRE Guy, L’Amérique latine et le latino-américanisme en France, París, L'Harmattan, 1985.

GIUNTA Andrea, Vanguardia, internacionalismo y política. Arte argentino en los sesenta, Buenos Aires, Paidós, 2001.

JAMESON Frederic, Periodizar los '60, Córdoba, Alción, 1997.

MALOSETti Costa, Laura, “¿Verdad o belleza ? Pintura, fotografía, memoria, historia”, in Revista de Critica Cultural vol. 4 n. 2, Universidade do Sul de Santa Catarina, Santa Catarina, 2009, pp.

111-123.

MARCHESI Mariana, 'Redes de arte revolucionario: el polo cultural chileno-cubano, 1970-1973', in A Contracorriente. A journal social history and literature in Latin America, vol.8, n.1, 2012, pp. 120-162. http://www.ncsu.edu/acontracorrient...

MOLLoY Sylvia, La diffusion de la littérature hispano-américaine en France au XXe siècle, Paris, Presse Universitaire Française, 1972.

NOUZEILLES Gabriela (comp.), La naturaleza en disputa. Retóricas del cuerpo y el paisaje en América Latina, Buenos Aires, Paidós, 2000.

PLANTE Isabel, “La multiplicación (y rebelión) de los objetos. Julio Le Parc y la consagración europea del arte cinético", in Isabel PLANTE y Cristina RossI, XIII Premio Fundación Telefónica a la investigación en historia de las artes plásticas en la Argentina. Buenos Aires, FIAAR- Fundación Espigas, 2010, pp. 15-74.

PLANTE Isabel, "El arte entre paréntesis. La centralidad del otro en el Atelier Populaire de 1968", in VI Congreso Internacional de Teoría e Historia de las Artes / XIV Jornadas CAIA, La autonomía del arte: debates en la teoría y en la praxis, Buenos Aires, CAIA, 2011, pp. 235-246.

PLANTE Isabel, Argentinos de París. Arte y viajes culturales durante los años sesenta, Buenos Aires, Edhasa, 2013.

REVEL Jean-François, Ni Marx ni Jésus. De la seconde révolution américaine à la seconde révolution mondiale, Paris, Robert Laffont, 1970. 
RICCARDI Teresa, 'Archivar mitologías: documentos secretos de una mirada femenina. ¿Cómo leer las vitrinas y las imágenes de Lea Lublin?', in Art and Archives. Latin American Art Forum 1920 to Present. II International Forum for Emerging Scholars, Oct 15-17, 2010, The Universtity of Texas, Austin, 2010.

Rolland Denis y ToUZAlin Marie-Hélène, "Un miroir déformant ? Les latino-américains à Paris depuis 1945", en Antoine Marès y Pierre Milza (dir.), Le Paris des étrangers depuis 1945. Paris, Publications de la Sorbonne, 1994, pp. 263-291.

Ross Kristin, Fast cars, clean bodies: decolonization and reordering of French culture, MIT Press, 1995.

SCHOR Naomi, "The crisis of French Universalism”, in Yale French Studies n.100. France / USA.

The cultural wars. Yale University Press, 2001, pp. 43-64.

TERÁN Oscar, Nuestros años sesentas. La formación de la nueva izquierda intelectual en la Argentina, 1956-1966. (1991)Buenos Aires, Puntosur.

\section{NOTAS}

1. La Coopérative des Malassis fue una agrupación conformada en 1970 por artistas ligados a la Figuración Narrativa: Henri Cueco, Lucien Fleury, Jean-Claude Latil, Michel Parré, Gérard Tisserand y Christian Zeimert.

2. Claudia Gilman, Entre la pluma y el fusil. Debates y dilemas del escritor revolucionario en América Latina. Buenos Aires, Siglo Veintiuno, 2003.

3. Esto no significa que no hubiera un campo artístico local de gran interés. Pero para quienes ambicionaban una proyección internacional, París resultaba un destino atractivo y prometedor.

4. Lambert había trabajado como traductor del español y su interés por la cultura latinoamericana se combinaba con su cercanía al Partido Comunista Francés. Su trayectoria tiene varios puntos en común con la de Jean Cassou, al frente del Musée National d'art Moderne desde 1945 hasta 1965. Sobre la actuación en relación con el arte argentino de Lambert y Cassou, y también de otros críticos franceses como Gérald Gassiot-Talabot, Pierre Gaudibert y Pierre Restany, véase Isabel Plante, Argentinos de París. Arte y viajes culturales durante los años sesenta. Buenos Aires, Edhasa, 2013.

5. Carta dirigida a los "Chers collègues" por el Comité de organización (Gerardo Chávez, Antonio Dias, Leonardo Delfino, Silvano Lora, Artur-Luiz Piza, Gina Pellom y Denys Chevalier como délégué général) 10 de mayo de 1968, sin firmar. Archivo Le Parc.

6. En los curriculum vitae de Marta Boto y de Vardánega figura un "Salón Latinoamericano, París" de 1968 pero éste no aparece en las biografías de Le Parc ni en los archivos del MAMVP.

7. Julio Le Parc, "L'Amérique Latine non officielle" (1970), en Jean-Louis Pradel, Julio Le Parc, Milano, Edizioni d'Arte Severgnini, 1995, p. 322.

8. Entrevista a Le Parc de Mathieu Alain y Jean-Paul Giubergia, [c.1973], 7 pp. dactilografiadas. Archivo Le Parc.

9. Julio Le Parc, "L'Amérique Latine non officielle" (1970), op.cit., p. 322-323

10. “L'écran du réel' Entretien avec Léa Lublin par Jérôme Sans" en Lea Lublin: Mémoire des lieux, mémoire du corps. Centre d'art contemporaine Quimper, Quimper, 1995. p. 37.

11. “Lea Lublin. Parcours conceptuel 1965-1975”, 3pp. mecanografiadas. Archivos MNBA.

12. Lea Lublin, "Dentro y fuera del museo", Artinf, Buenos Aires, julio 1971.

13. “'Cultura fuera y dentro del museo', una investigación del conocimiento”, La Opinión, Buenos Aires, 21/1/1972. Archivos MNBA. 
14. Ernesto Saúl, “Juegos respetuosos” Ahora, Santiago de Chile, 28/12/1971. Archivos del Museo Nacional de Bellas Artes, Santiago de Chile. Mi gratitud a Samuel Quiroga por su generosa ayuda. 15. Aquí es importante aclarar que la artista realizó una serie de planos, y que entre este proyecto y las posibilidades concretas para su realización hubo cierta distancia. Distancia que no siempre es posible medir, dada la cantidad acotada de fotografías disponibles de la obra.

16. Tal es el caso, por ejemplo, del texto de Teresa Riccardi ya citado y de Françoise Ducros, "Mémoire des lieux, mémoire du corps, dit-elle" en Lea Lublin : Mémoire des lieux... op cit.

17. El grupo estaba integrado por Horacio García Rossi, Julio Le Parc, François Morellet, Francisco Sobrino, Joel Stein y Jean-Pierre Yvaral. Su actividad se extendió desde 1960 hasta 1968.

18. La situación política de Sudamérica cambió de manera radical a partir de los golpes de Estado de 1973 en Chile y Uruguay, de 1975 en Perú y de 1976 en Argentina, que sumaron nuevos regímenes militares a los ya instalados en Paraguay, Brasil y Ecuador.

19. Bernard Teyssèdre, "Le parcours de Lea Lublin" 12 pp. dactilografiadas. Archivos MNBA.

20. "La tercera partida", Análisis n. 462, 20/1/1970, pp. 49-50.

21. Entrevista con la autora con Seguí, $8 / 5 / 2008$.

22. Carta de Antonio Seguí a Edward Shaw 16/11/1963, en "Cronología”, Antonio Seguí. Exposición retrospectiva 1958-1990. Buenos Aires, MNBA, 1991, p. 158. Según relata Damián Bayón, a André Malraux le gustaron las telas de Seguí y el crítico Claude Bernard hizo buenos comentarios lo que contribuyó a que vendiera la mayor parte de las obras: "diez, doce telas fueron a parar a los museos más importantes de Europa”. Damián Bayón, Aventura plástica de Hispanoamérica. Pintura, cinetismo, artes de la acción (1940-1972). México, FCE, 1974, p. 265. En el catálogo sólo figuran cuatro óleos de Seguí junto con obras de Carlos Alonso, Esperilio Bute, Félix Cuello, Rómulo Macció, Rogelio Polesello, Hugo Rodríguez, Olimpia Ogilve y Nicolás Rubio. "Argentine”, en Torisième BIennale de Paris. Musée d'Art Moderne de la Ville de Paris, 28 septembre au 3 novembre 1963, pp. 22-23.

23. Carta de Seguí a Edward Shaw, 9/1/1964, citada en "Cronología", Antonio Seguí... op. cit.., p. 158.

24. En Claude Bernard exponían pintores jóvenes como Fernando Botero, David Hockney y también Francis Bacon.

25. "Argentinos en París", Cofirmado n. 1, 7/5/1965, p. 26. En una carta del 17 de marzo de 1964, Seguí le contaba a Shaw que había cerrado contrato con una de esas galerías, "Cronología", Antonio Seguí.... op. cit., p. 158.

26. Entrevista con Seguí, ya citada. Los tres artistas alquilaron una suerte de galpón, el garage de una casona en la localidad de Arcueil, en 1964. La fiesta más recordada y de la que el artista conserva documentación fue La Fête Garde-Robe de 1965, a la que cada asistente debía llevar una obra con el tema 'guardarropas'. Seguí confeccionó una escultura de grandes dimensiones representando un calzoncillo con una sola pierna. Asistieron unas 600 personas, Berni, Bayón y Copi entre ellos. "Biografía”, Antonio Seguí..., op. cit., p. 158.

27. Entrevista a Seguí, en Ana Borón, Mario del Carril y Albino Gómez, Porqué se fueron. Testimonios de argentinos en el exterior. Buenos Aires, Emecé, 1995, p. 167.

28. "Exposition -Vente. Les 6 et 7 juillet de 10 à 22 heures". Galerie du Dragon, Paris, s/d. Archivo Le Parc. Sobre la participación de Seguí en las iniciativas artísticas desarrolladas durante el Mayo francés, véase en el artículo de mi autoría, "El arte entre paréntesis. La centralidad del otro en el Atelier Populaire de 1968", VI Congreso Internacional de Teoría e Historia de las Artes / XIV Jornadas CAIA, La autonomía del arte : debates en la teoría y en la praxis, Buenos Aires, CAIA, 2011, pp. 235-246.

29. Hacia el mes de julio el Movimiento lanzaba la campaña "Luche y vuelve", en agosto tuvo lugar la ejecución de 16 presos políticos en Trelew (episodio que terminó de socavar la credibilidad del gobierno nacional) y el 17 de noviembre Perón regresó a Buenos Aires y participó 
de la creación del Frente Justicialista de Liberación Nacional, cuya fórmula encabezada por Héctor Cámpora ganó las elecciones de marzo de 1973.

30. Parafraseo aquí el libro compilado por Alfredo Pucciarelli : La primacía de la política. Lanusse, Perón y la Nueva Izquierda en los tiempos del GAN. Buenos Aires, Eudeba, 1999.

31. "La tercera partida", Análisis, nº 462, Buenos Aires, 20/1/1970, pp. 49-50.

32. Estas son las obras que reúne el catálogo razonado de Seguí, todavía en edición. Dado su éxito de mercado no siempre es posible recomponer las series, pues se han dispersado. Hemos encontrado mencionadas otras tres pinturas que posiblemente formen parte de esta serie : El Champaquí, Carlos Paz y Unquillo.

33. Gilbert Lascault, “Antonio Seguí. Entretien”, Beaux Arts, nº 5, Paris, septembre 1983, pp. 27-31.

34. Pierre Restany, “Art concepts from Europe”, Domus, n. 487, juin 1970, pp. 45-48.

35. Restany, Pierre, "Le pouvoir critique de la couleur" (1974), en Uriburu. Colorations 1968-1978, Paris, Damase, 1978, p. 16.

36. Nicolás García Uriburu, s/t (1971), en Uriburu..., op. cit., p. 4.

37. Juan Domingo Perón, La hora de los pueblos, Madrid, Norte, 1968.

38. Néstor García Canclini, "Vanguardias artísticas y cultura popular", Transformaciones n. 90, Buenos Aires, Centro Editor de América Latina, 1973.

39. Portfolio (Manifiesto) (1973), 6 serigrafías de 75 x $55 \mathrm{~cm}$,, cada una.

40. Amazonia aparece como lugar asociado a una serie de imágenes de la abundancia que tuvieron diversas fortunas y reformulaciones desde la misma conquista de América. Véanse Gabriela Nouzeilles (comp.), La naturaleza en disputa. Retóricas del cuerpo y el paisaje en América Latina. Buenos Aires, Paidós, 2002. Dentro del marco de esta investigación, Amazonia aparece en términos de paraíso natural en la perspectiva de Pierre Restany y como pasaiso sexua en las tiras cómicas y la narrativa de Copil. Véanse, de mi autoría "Pierre Restany et l'Amérique Latine. Un détournement de l'axe Paris-New York", en Richard Leeman (dir.), Le demi-siècle de Pierre Restany. Paris, Institut National d'Histoire de l'Art - Éditions des Cendres, 2009, pp. 287-309; y "Recorridos de La mujer sentada. Las tiras cómicas de Copi entre París y Buenos Aires", en Antiteses, v. 5, n. 9, janeiro-junio de 2012, Universidade Estadual de Londrina, Brasil. http:// www.uel.br/revistas/uel/inde...

\section{RESÚMENES}

La cuestión de la especificidad cultural y de los viajes intelectuales recorre la historia del arte moderno argentino y latinoamericano. Pero durante los años sesenta, el deseo de proyección internacional del arte, la emigración más numerosa de artistas e intelectuales, y la interpelación latinoamericanista les insuflaron una nueva escala y otros pliegues de sentido. Este artículo rastrea y explora los impactos de la extranjería en el trabajo de algunos de los "argentinos de París" -Julio Le Parc, Nicolás García Uriburu, Lea Lublin y Antonio Seguí- aun cuando en las artes visuales no media, necesariamente, el problema de la lengua. Se analizan las maneras en que cada uno de estos migrantes moduló en su obra las nociones de lugar y de distancia.

Avec les voyages des intellectuels et des artistes, la question de la spécificité culturelle argentine et latino-américaine traverse l'histoire de l'art moderne. Mais pendant les années 1960, l'émigration plus nombreuse des artistes et l'interpellation latino-américaine ont posé cette question avec une acuité nouvelle, et les réponses ont elles-mêmes été plurielles. Cet article 
explore l'impact du déracinement sur le travail de quelques « Argentins de Paris » - tels Julio Le Parc, Nicolás García Uriburu, Lea Lublin y Antonio Seguí -, même si le problème de la langue n'intervient pas nécessairement dans les arts visuels. On analyse ainsi comment chacun de ces migrants a intégré les notions de lieu et de distance dans ses œuvres.

ÍNDICE

Mots-clés: années 1960, relations France-Argentine, émigration, Julio Le Parc, Nicolás García Uriburu, Lea Lublin, Antonio Seguí

Palabras claves: años 1960, relaciones Francia-Argentina, emigración, Julio Le Parc, Nicolás García Uriburu, Lea Lublin, Antonio Seguí

\section{AUTOR}

\section{ISABEL PLANTE}

Conicet, Idaes-Unsam 